\title{
Przygotowanie i spożywanie posiłków w świetle zabytków metalowych pozyskanych na stanowisku przy ulicy Wałowej 40 w Gdańsku
}

\author{
Preparation and Consumption of Meals in the Light \\ of Metal Artefacts Discovered at Site Wałowa 40 in Gdańsk
}

\begin{abstract}
Abstrakt: Artykuł stanowi opracowanie 31 zabytków używanych podczas przygotowania oraz konsumpcji posiłków, pozyskanych ze stanowiska przy ulicy Wałowej 40 w Gdańsku. Pośród wymienionych w pracy obiektów można wskazać Is łyżek, I3 noży, w tym jeden tworzący komplet z widelcem, drugi dwuzębny widelec oraz cynowy kufel. Przedmiotem analizy jest forma i zdobienie zabytków oraz kwestia znaków wytwórców. Szczególną uwagę zwrócono na komplet sztućców złożony z noża oraz dwuzębnego widelca i kolejny widelec tego typu. Sztućce te mogły być wykorzystywane do nakładania potraw z półmisków. Warte podkreślenia jest
\end{abstract}

również potwierdzenie lokalnej proweniencji niektórych z łyżek lub nawet wskazanie gdańskiego wytwórcy, partacza Petera Dralanda. Znalezisko wyjątkowe, podnoszące walory wystawiennicze zbioru, to cynowy kufel. Zabytki z tego metalu, z uwagi na powiązane z nimi aspekty finansowe i społeczne, takie jak: duże zainteresowanie nabywców, kwestie jakości i walki cechu z partaczami, stanowią również punkt wyjścia do szerszej refleksji nad gdańskim konwisarstwem. Omawiane artefakty pozyskano z kontekstu datowanego na okres od drugiej połowy XVI po XVIII w. Chronologię przedmiotów ustalono jednak w większości przypadków na XVII stulecie.

Słowa kluczowe: artefakty kuchenne, zastawa stołowa: noże, łyżki, kufel, wyroby z mosiądzu i cyny, znak producenta

W sezonach 2016 i 2017 Pracownia Badań Archeologicznych Azupiranu, pod kierownictwem Anny Longi przeprowadziła prace w Gdańsku, na stanowisku przy ulicy Wałowej 40 (działka o numerze ewidencyjnym 434/15, obręb 090). Badania objęły obszar zlokalizowany pomiędzy ulicami Aksamitną, Wałową i Rybaki Górne, w północno-wschodniej części Starego Miasta (ryc. I).

Pierwotnie stanowisko znajdowało się na styku trzech równolegle rozwijających się organizmów miejskich: Osieka, Starego Miasta i Młodego Miasta. W I 402 r. teren został wcielony do osady Osiek, a pod koniec XV stulecia do Starego Miasta ${ }^{1}$.

1 https://www.gedanopedia.pl/index.php?title=osiEk [26 VI 2019]. 


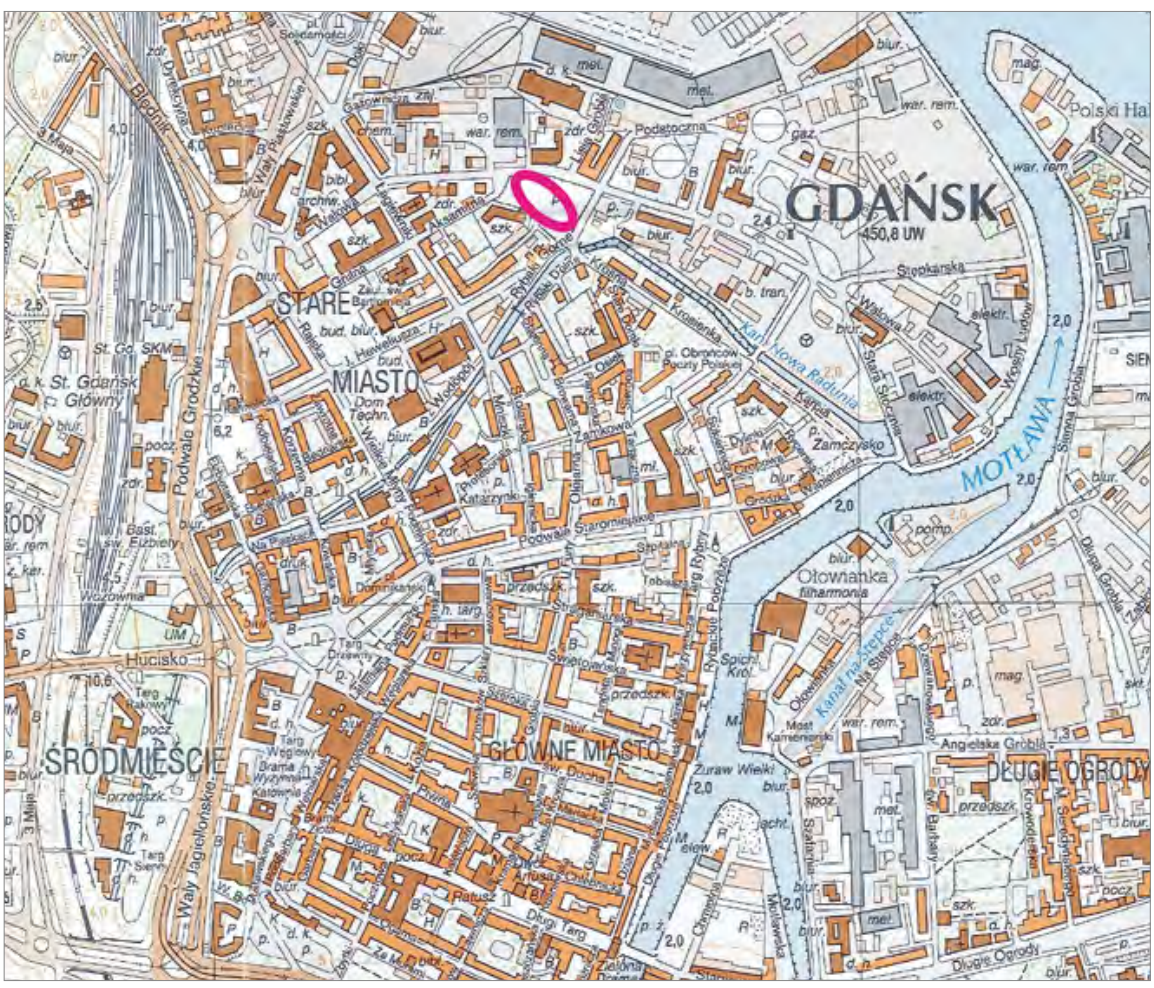

Ryc. 1. Lokalizacja stanowiska przy ulicy Wałowej 40.

Od końca XIV w. planowano otoczenie Starego Miasta wałem, a w I 402 r. uzyskano zezwolenie na wykopanie fosy o szerokości I2 m (Nowy Rów) zlokalizowanej pomiędzy Starym a Młodym Miastem. Nad fosą zbudowano most. Pozyskana podczas kopania fosy ziemia posłużyła obu miastom do sypania wałów obronnych. W latach I 447-I480 rozpoczęto budowę murów obronnych Starego Miasta, które na mocy wielkiego przywileju wydanego przez Kazimierza Jagiellończyka weszło w skład Gdańska² (ryc. 2). Kolejna, poważna zmiana oblicza dzielnicy nastąpiła dopiero na początku XVII w. Przekształcenia były związane ze wznoszeniem frontu północnego nowożytnych fortyfikacji miejskich. Nasilone w latach 20. i 30 . XVII w. prace ${ }^{3}$ stanowiły reakcje na zagrożenie ze strony Szwecji. Po budowie umocnień północna część miasta w prawie niezmienionej formie przetrwała do końca XIX w. (Sprawozdanie z badań... 2017: 7) (ryc.3). Lata 80. tego stulecia

2 http://www.gedanopedia.pl/gdansk/?title=STARE_MIASTO [24 VI 2019].

3 https://www.gedanopedia.pl/gdansk/?title=FORTY FIKACJE [24 VI 20I9]. 


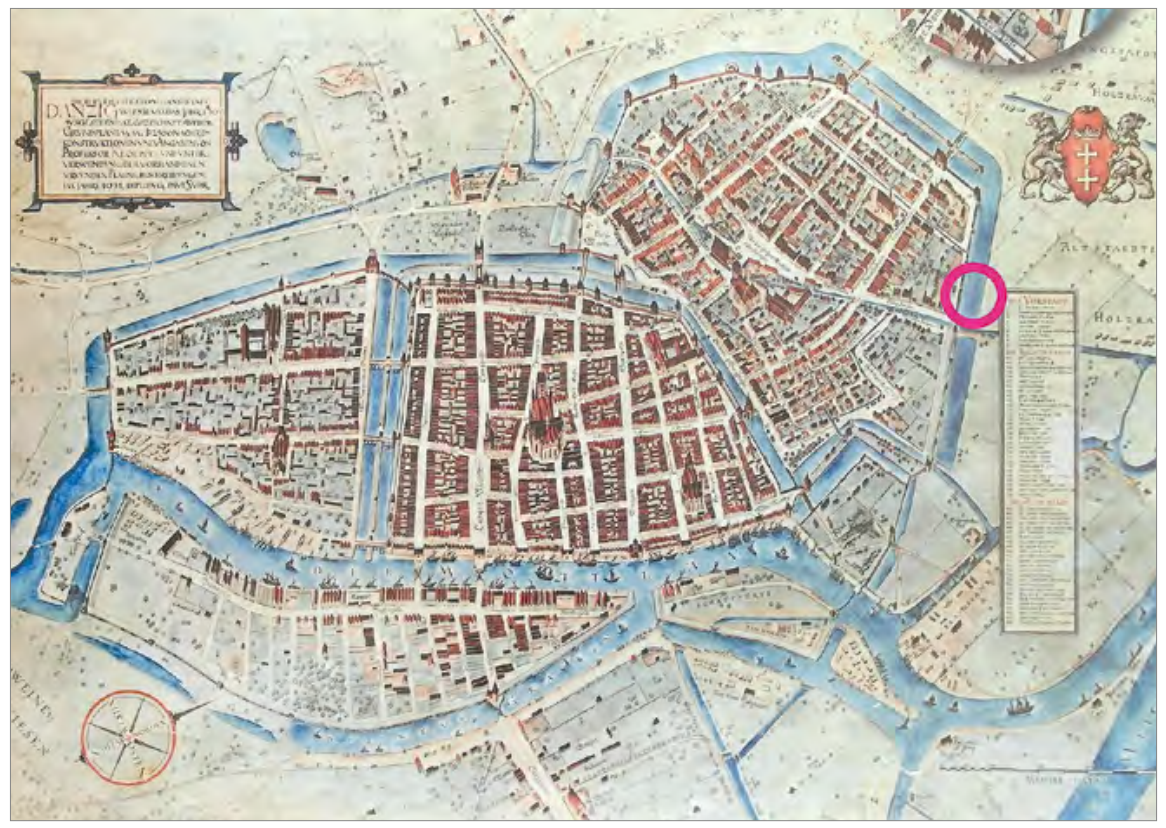

Ryc. 2. Plan Gdańska Otto Kloeppela z I93I r. przedstawiający miasto około I50o r., z zaznaczoną lokalizacją stanowiska, https://gdansk.fotopolska.eu/696i5o,foto.html [25 VI 2019].

przyniosły wynalazek granatów burzących. Sprawiły one, że nowożytne fortyfikacje przestały pełnić swoją funkcję. Skłoniło to władze wojskowe do rozbiórki ciągu obwałowań linii zachodniej oraz północnej. Większa część pasa północnego pozostała w rękach wojska, które niezwłocznie po decyzji o defortyfikacji dokonało niwelacji bastionów Lis i Ryś (okolice stanowiska). Na ich miejscu wzniesiono magazyny i stajnie wojskowe (Omilanowska 20I0: 310), a na obszarze uzyskanym po likwidacji kurtyny pomiędzy Bastionami św. Jakuba i Lis od I892 r. funkcjonował zespół Zakładów Mundurowych Korpusu. W jego skład weszły budynki warsztatu, zarządu, magazynów i mieszkań dla pracowników (Omilanowska 20ı: 3II). Zmiany koncepcji zagospodarowania objęły również teren badań. W drugiej połowie XIX w. od strony obecnej ulicy Rybaki Górne pojawiła się zabudowa mieszkalna oraz gospodarcza (Sprawozdanie z badań... 20I7: II), a przy ulicy Aksamitnej od ı880 r. mieściły się koszary wojskowe (Sprawozdanie z badań... 2017: 19).

Proces zagospodarowania terenu przy ulicy Wałowej 40 znany ze źródeł pisanych został potwierdzony w trakcie prac archeologicznych. Stanowisko znajduje się na obszarze, który stał się przedpolem późnośredniowiecznych murów obronnych miasta, w skład którego wchodziła zlokalizowana podczas badań fosa (Sprawozdanie z badań... 20I7: 8, I0). W XVII w., w związku z budową północnego frontu 


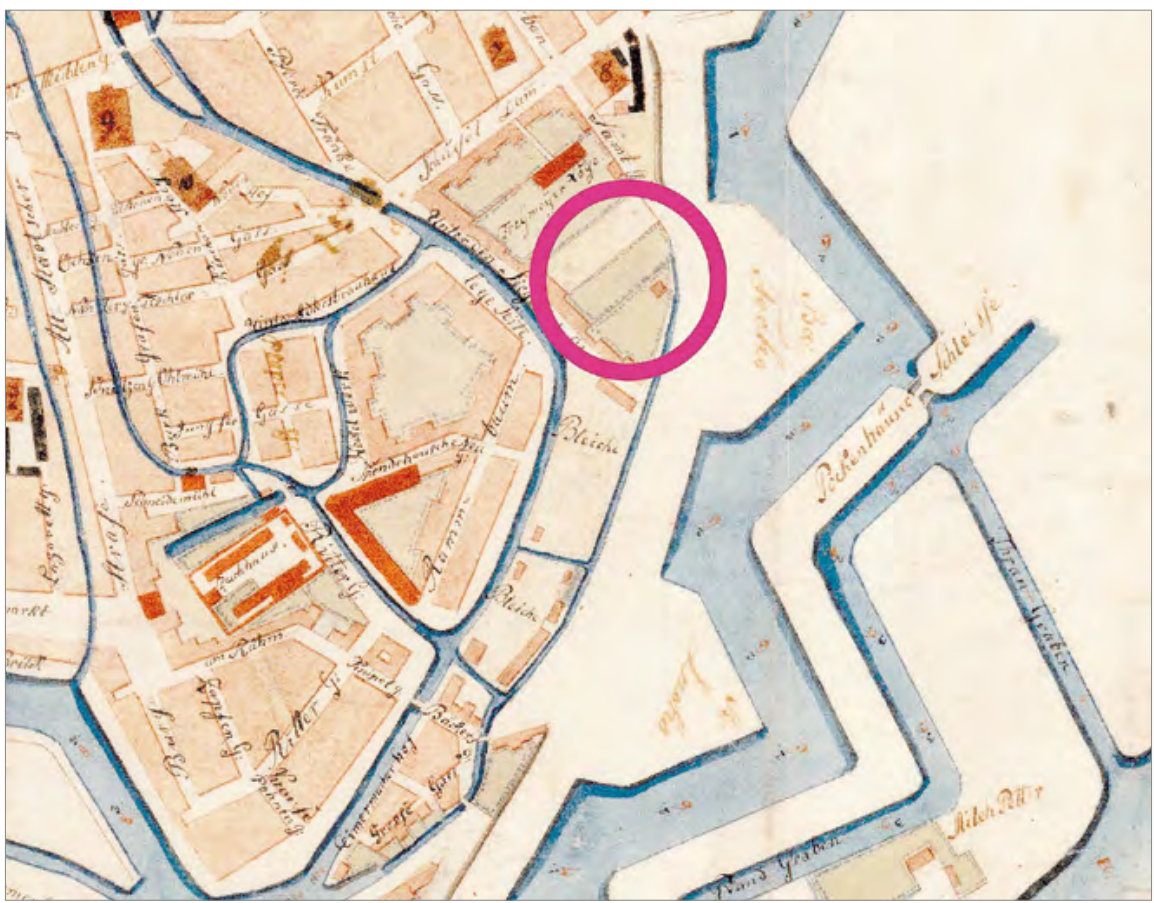

Ryc. 3. Fragment planu Gdańska Büttnera z I809 r., z zaznaczoną lokalizacją stanowiska (APG, 300, MP/398).

nowożytnych fortyfikacji, fosa ta została zasypana śmieciami zwożonymi z miasta ${ }^{4}$. Teren został zniwelowany i przekształcony w ogrody, po których pozostały karpy drzew owocowych (Sprawozdanie z badań... 2017: 8, I0). Podczas badań w 2017 r. odsłonięto również relikty XIX-wiecznej zabudowy. Były to partie fundamentowe wschodniego skrzydła budynku koszar oraz wolnostojącego obiektu, prawdopodobnie o funkcji magazynowej. Zabudowa została zniszczona w 1945 r. (Sprawozdanie z badań... 2017: 19, 20). Teren zniwelowano i w tej formie pozostawiono aż do momentu wykopalisk (Sprawozdanie z badań... 2017: iı). Oprócz odsłonięcia wspomnianych reliktów, pozyskano znaczną liczbę zabytków ruchomych

4 Praktykę relokacji śmieci na przedmieścia potwierdzają badania archeologiczne w innych rejonach Gdańska. Na zachód od Głównego Miasta, na obszarze obecnego Targu Siennego, nieczystości z podwórek kamienic i ulic miasta oraz materiał rozbiórkowy posłużył prawdopodobnie do podniesienia poziomu użytkowego. Te działania tłumaczą olbrzymią liczbę (ponad 7 tys.) zabytków o walorach wystawienniczych, pozyskanych z tego stanowiska (Targ Sienny... 2016: 7). W ten sposób podniesiono też poziom użytkowy na terenie podmokłym, na wschód od Motławy, w zachodniej części gdańskiej dzielnicy Długie Ogrody (Krzywdziński 2013: 30). 
(Sprawozdanie z badań... 2017: II). Wśród nich około półtora tysiąca przedmiotów metalowych o walorach wystawienniczych.

Celem artykułu jest prezentacja odkrytego podczas badań zbioru 3I zabytków metalowych, które można łączyć z przygotowaniem oraz konsumpcją posiłków, z czego 29 z tych obiektów to elementy zastawy stołowej (ryc. 4: I-8; 5: I-3; 6: I-2; 8; IO: I-5; II: I-7; I2; I3; I6). Wśród nich dominują tyżki wykonane z cyny (I3 egz.) (ryc. IO; II; I3). Do tej grupy należy włączyć także łyżkę żelazną, pokrytą pierwotnie cyną (ryc. I2). Kolejną grupę stanowią noże. Ta kategoria zabytków sprawia liczne problemy badawcze. Przyporządkowane do niej artefakty mogły mieć różne, szerokie bądź wąskie zastosowanie (Trawicka 2018: 342,343; Wieczorek-Kańczura, Szajt 2018: 296). Wskazana grupa zabytków była więc obecna w wielu aspektach ludzkiej egzystencji: od gospodarstwa domowego, poprzez warsztat pracy, aż po pole walki (Michalik 2007: 43-52; Kasprzak 2013: 309; Gomoliszek 2016: 430-43I). W literaturze przedmiotu noże omawiane są jako kategoria nadrzędna, z próbą ustalenia ich funkcji. Stale reprezentowane są grupy noży stołowych oraz kuchennych. Na stanowisku przy ulicy Wałowej 40, we wspomnianych kategoriach, noże stołowe stanowią drugą pod względem liczebności grupę (I2 egz., ryc. 4; 5; 6: I). W jej skład wchodzi również egzemplarz (ryc. 6: I), który pierwotnie tworzył komplet z widelcem (ryc. 6: 2). W trakcie badań pozyskano dwa tego typu dwuzębne, żelazne widelce (ryc. 6:2;8). W charakteryzowanym zespole znajduje się również, uznany za obiekt wyjątkowy, cynowy kufel (ryc. 16). Słabiej reprezentowane są sprzęty kuchenne. Do przedmiotów wykorzystywanych podczas gotowania można zaliczyć jeden nóż (ryc. 9) oraz niewielkążelazną łyżkę z tuleją (ryc. 14). Niewielka liczba znalezisk może wynikać ze stanu zachowania tej kategorii przedmiotów, co wpływa na trudności interpretacyjne. Sprzętów kuchennych nie przypominają spotykane często na stanowiskach, wykonane z miedzianej blachy łaty, z których nitowano kotły, czy żelazne pręty, które pierwotnie były częścią rusztu. Dlatego warto wspomnieć o kilku przedmiotach związanych z przygotowaniem posiłków. Niecodziennym znaleziskiem jest fragmentarycznie zachowany rożen z Targu Siennego - zachodniego przedmieścia Gdańska (Targ Sienny... 2016: 105 - poz. 178). Ewenement stanowi też kompletny kociołek wykuty z blachy miedzianej (Trawicka 2018:344, 370, ryc. 13: kat. 2647) odkryty w obrębie jatek mięsnych ${ }^{5}$. Należy zwrócić również uwagę na dwie żelazne łyżki kuchenne pozyskane na stanowisku (Trawicka 2018:344, 370, ryc. 13: kat. 2641, 2642). Pewne wyobrażenie o wyposażeniu średniowiecznej kuchni dają natomiast ostatnie odkrycia wrocławskie. Z placu Nowy Targ pochodzą m.in. dwie fragmentarycznie zachowane żelazne patelnie (Wieczorek-Kańczura 2018: 292, 293, 295, ryc. 191: a, b).

5 Stanowisko zlokalizowane w kwartale znajdującym się przy kościele pw. Najświętszej Marii Panny: pomiędzy ulicami Mariacką a Sw. Ducha, na Głównym Mieście. 


\section{Stan badań}

Pozyskane podczas badań archeologicznych metalowe elementy zastawy stołowej i sprzęty kuchenne to kategorie słabo omówione w polskiej literaturze przedmiotu. Brak prac poświęconych wyłącznie tej grupie materiałów archeologicznych, są one jedynie wzmiankowane w zbiorczych, monograficznych opracowaniach stanowisk (Konczewska, Konczewski 2004: 95-98, II2, I19; Wrak statku... 2008: 385-388, 398-399; Trawicka 2018: 344, 370; Wieczorek-Kańczura 2018: 287-296; Trawicka 2020b: 329-332, 347). Lepiej w literaturze wygląda stan badań nad nożami, przy czym dla odkrytych egzemplarzy kluczowe są dwie publikacje przybliżające gdańskie zabytki tej kategorii. Pierwsza, autorstwa Moniki Kasprzak (2013: 309-336), obejmuje znaleziska z południowo-zachodniej części kwartału ulic: Długie Ogrody, Szafarnia, Angielska Grobla i Św. Barbary. Druga, napisana przez Alicję Gomoliszek (2016: 377-454), stanowi opracowanie artefaktów z parceli przy ulicy Chmielnej 73-74 (południowa część Wyspy Spichrzów). Artykuły bazują na wcześniejszej monografii Przemysława Michalika (2007) omawiającej późnośredniowieczne i wczesnonowożytne noże z zamku w Pucku oraz niepublikowanej, napisanej w UMK pracy magisterskiej (Jędrzejczak 2004) prezentującej przedmioty z Wyspy Spichrzów w Gdańsku' ${ }^{6}$ Istotną pozycję stanowi również analiza 483 noży pozyskanych podczas badań we Wrocławiu na placu Nowy Targ. Jest to najliczniejszy dotychczas publikowany zbiór z terenu Polski (Wieczorek-Kańczura, Szajt 2018: 296-322).

Zastawę stołową tworzyły często obiekty wykazujące walory artystyczne, a przez to cenne. Część z nich przetrwała i obecnie wchodzi w skład kolekcji muzealnych lub prywatnych. $\mathrm{Z}$ tego względu istotne dla uzupełnienia wiedzy w tej materii są wyniki prac historyków sztuki. W badaniach nad gdańskim konwisarstwem kluczowe są pozycje Barbary Tuchołki-Włodarskiej. Pierwsza z nich to katalog cynowych naczyń codziennego użytku oraz sprzętów kościelnych (Włodarska 1975) pochodzących ze zbiorów Muzeum Narodowego w Gdańsku. Stale powiększający się inwentarz oraz dalsze badania nad gdańskim i pomorskim konwisarstwem doczekały się w 1992 r. nowego opracowania (Tuchołka-Włodarska 1992). Cennych informacji dostarczają również artykuły badaczki zawarte w „Gdańskich Studiach Muzealnych”. Autorka porusza kwestię jakości cyny prezentowaną w świetle znaków gdańskich konwisarzy (Tuchołka-Włodarska 1978: 77-98). Natomiast gdański rynek przedmiotów cynowych omawiany jest w kontekście konwisarstwa pozacechowego oraz importów angielskich naczyń (Tuchołka-Włodarska 1981: 65-82). O aspekcie estetycznym można mówić

6 W ostatnim tomie (t. 7) Archeologii Gdańska badaczka omawia 360 noży z wykopalisk na terenie stoczni Lastadia (Jędrzejczak-Skutnik 2020: 40I-424). 
w przypadku wyjątkowego kompletu sztućców (ryc. 6: I, 2). Jego znaczenia kulturowego dotyczy opracowanie Jacka Kriegseisena (2015: 93-104).

Noże to kategoria zabytków archeologicznych, w przypadku której bogatsza jest literatura zagraniczna. Tą problematyką w skali europejskiej zajęli się badacze niemieccy G. Folke i W. Holtmann (1993), analogi może dostarczyć również kilkutomowa praca J. Amme (2002; 2007; 2012), która stanowi omówienie zabytków z Niderlandów, Niemiec i Anglii. Odnośnie do cynowych elementów zastawy stołowej materiału porównawczego można szukać w publikacji artefaktów pozyskanych w Amsterdamie, autorstwa J. Baarta i W. Krooka (1977: 294-324, 338-344). Pomocne są również prace anglojęzyczne H.H. Cotterela (1969), D.W. Halla i J. Gadda (200I) czy katalog zabytków z muzeum w Birmingham (Old Pewter... bd).

\section{Analiza noży stołowych i kuchennych. Stan zachowania}

Wśród I3 noży z ulicy Wałowej 40 wyróżniono sześć brzeszczotów zachowanych w całości. W dwóch przypadkach pozostała również rękojeść w formie kościanego lub wykonanego z poroża trzonka (ryc. 4: 8; 6: I) albo okładzin z drewna (ryc. 4: 7). Pośród egzemplarzy zniszczonych dużą grupę tworzą noże z uszkodzoną w mniejszym (ryc. 4: I) lub większym stopniu (ryc. 4: 2-5; 5: I; 9) głownią. W przypadku tych zabytków stwierdzono rękojeść, odlewaną, kutą bądź wycinaną, wykonaną z: żelaza (ryc. 4: I, 5), mosiądzu (ryc. 4: 2, 4), kości lub poroża (ryc. 4: 3; 9) bądź drewna (ryc. 5: I). Znaczne zniszczenie głowni sześciu noży, stanowiące efekt uszkodzenia mechanicznego lub spowodowane korozją, utrudnia ocenę ich pierwotnej formy. Jednak ogólny pokrój egzemplarzy: rozmiar czy forma rękojeści pozwala na zaliczenie ich do kategorii noży stołowych (ryc. 4: I-5; 5: I).

\section{Budowa}

Sposób ukształtowania głowni

$\mathrm{Na}$ czterech egzemplarzach zaobserwowano sztych jednostronnie wydzielony, zwężający się od strony tylca (ryc. 4: 6; 5: 2, 3; 6: I). W zbiorze spotykany był też sztych zwężający się od ostrza i jednocześnie nieznacznie od tylca (ryc. 4: 7, 8). Prawie we wszystkich przypadkach można mówić o prosto uformowanym tylcu. Natomiast ostrze przybierało kształt mniej (ryc. 4: 6, 8; 6: I; 9) lub bardziej (ryc. 5:3) ukośny, albo w większym (ryc. 4: I; 5:2) lub mniejszym (ryc. 4: 7) stopniu tukowaty.

\section{Konstrukcja rękojeści}

W ośmiu przypadkach stwierdzono obecność trzpieni (ryc. 4: 2, 3, 6, 8; 5: I-3; 6: I), a w trzech sztabki do osadzenia rękojeści (ryc. 4: 4, 7; 5), przy czym jeden z egzemplarzy charakteryzuje sztabka przechodząca przy końcu w trzpień (ryc. 4: 7). 


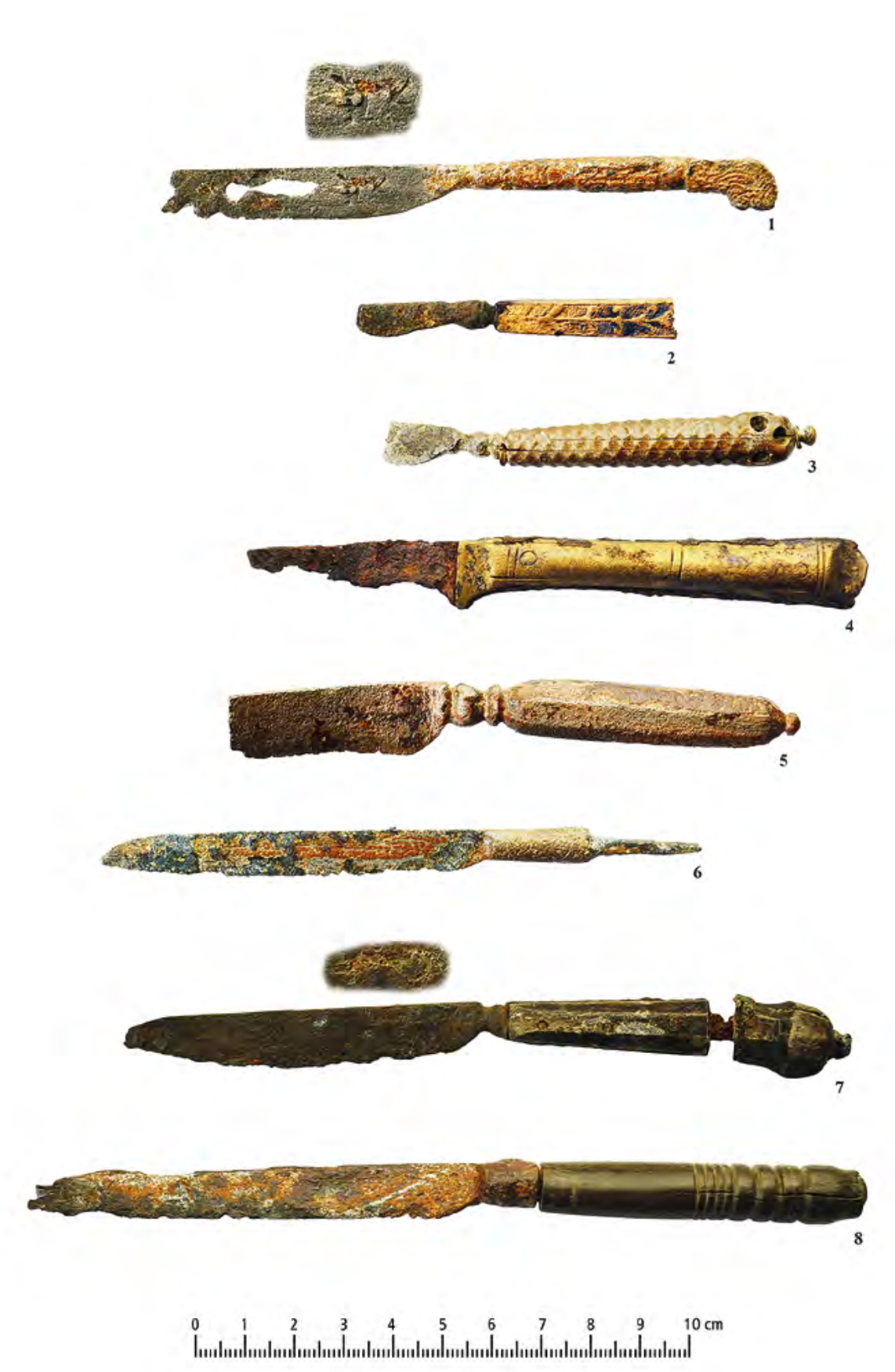

Ryc. 4. Noże stołowe (fot. M. Wołyńska). 


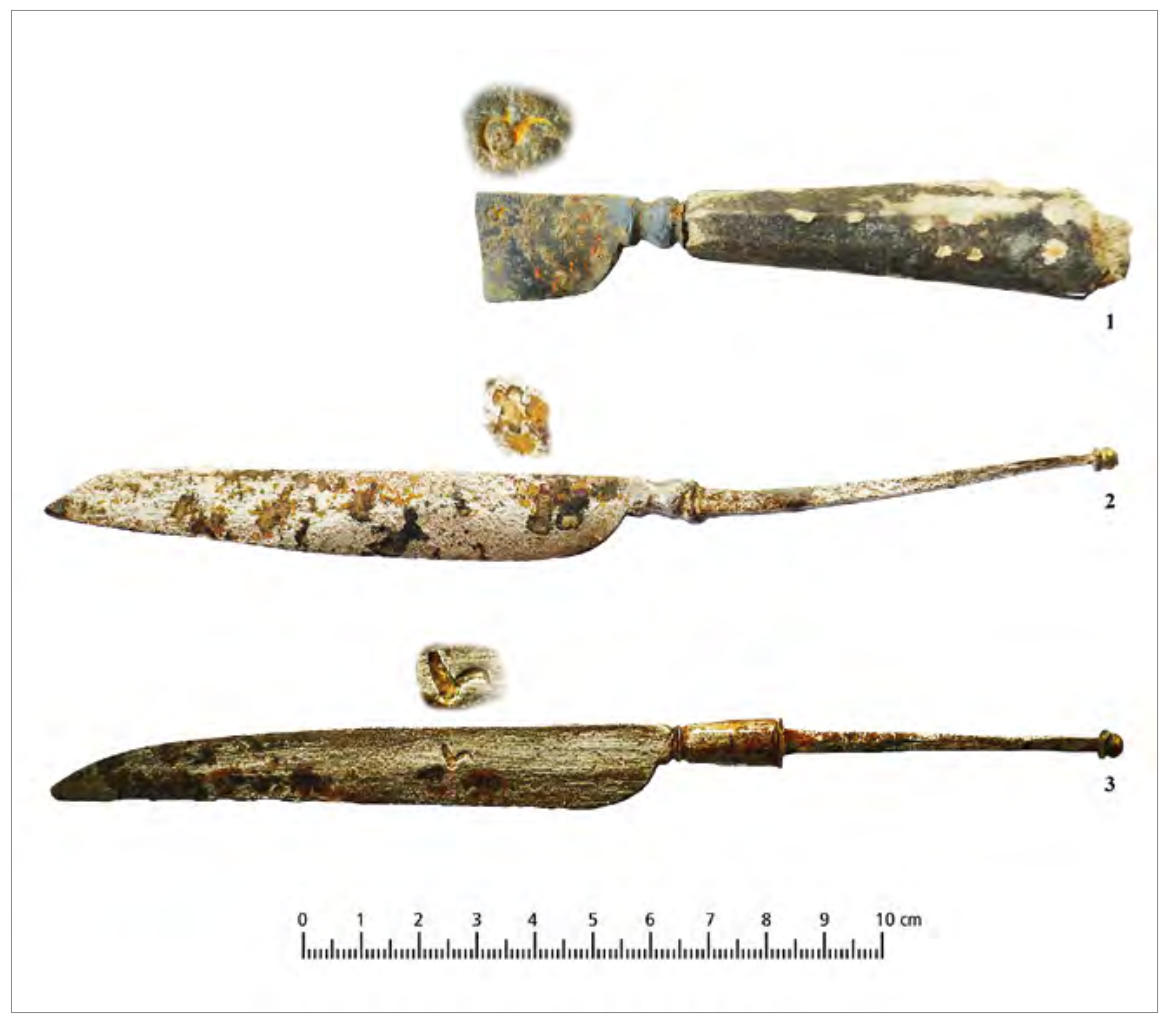

Ryc. 5. Noże stołowe (fot. M. Wołyńska).

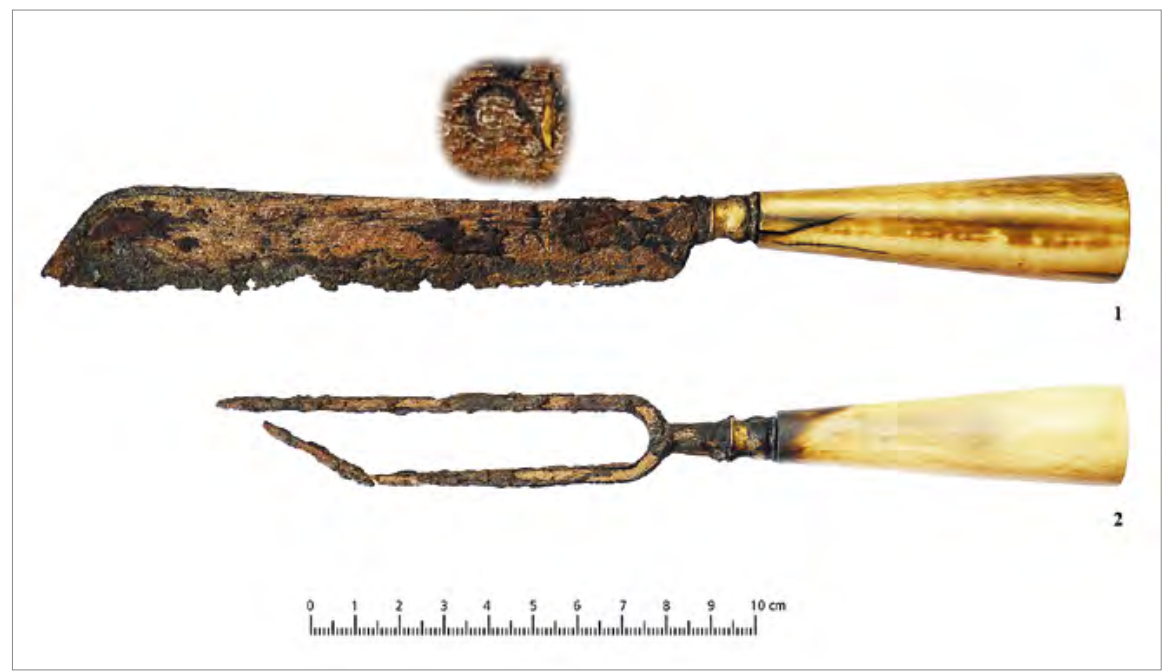

Ryc. 6. Komplet sztućców (fot. M. Wołyńska). 
Dwa z noży zostały wykonane z jednego kęsa żelaza (ryc. 4: I, 5), przez co rękojeść stanowi ich integralną część. Dominują rękojeści organiczne, w formie oprawki (ryc. 4: 3, 8; 5: I; 6: I) albo okładzin (ryc. 4: 7; I0): kościanych, rogowych (ryc. 4: 3, 8; 6: I; Io) lub drewnianych (ryc. 4: 7; 5: I). Dwa z noży zaopatrzono w rękojeść metalową, odlewaną (ryc. 4: 2) lub kutą (ryc. 4: 4). Okładzinom nadawano kształt półokrągły (ryc. 4: 4) lub trapezowaty (ryc. 4: 7). Oprawki ${ }^{7}$ przybierały formę stożkowatą (ryc. 4: 3; 6: I), miały przekrój kolisty (ryc. 4:3, 8; 6: I), czworoboczny (ryc. 4: 2) lub ośmioboczny (ryc. 5: I). Okładziny mocowano przy użyciu nitów. Ich obecność stwierdzono na trzech egzemplarzach. W dwóch przypadkach są to nity żelazne, pełne (ryc. 4: 7; 9), a w jednym mosiężne, lite (ryc. 4: 4).

\section{Sposoby zdobienia noży}

Interesujący aspekt stanowi zdobienie noży. Przemysław Michalik (2007: 63) podjął się rozdzielenia elementów wyłącznie dekoracyjnych od części o znaczeniu użytkowym, pełniących wtórnie rolę ozdoby. Wskazał również trzecią grupę, którą można lokować pomiędzy dwoma poprzednimi. Monika Kasprzak (2013: 314, 315) przyjęła dwa kryteria: pierwsze o charakterze czysto zdobniczym oraz drugie łączące funkcję konstrukcyjną z dekoracyjną. Podstawę do omówienia tego zagadnienia w zbiorze noży z ulicy Wałowej 40 stanowi ta druga publikacja.

Do pierwszej ze wskazanych kategorii można zaliczyć sześć zabytków (ryc. 4: I-4, 6, 8). Pierwszy z nich (ryc. 4: 3) charakteryzowała wykonana z rogu oprawka, o powierzchni fasetowanej w romby oraz osiem gniazd (średnicy $3 \mathrm{~mm}$, głębokości $2 \mathrm{~mm}$ ) wywierconych na końcu trzonka. Gniazda umieszczono w dwóch poprzecznych do osi trzonka rzędach. Być może pierwotnie osadzone były w nich szklane oczka(?). Kolejne trzy noże zdobią ornamenty ryte w formie: wykonanego na nasadzie głowni motywu wici roślinnej(?) (ryc. 4: 6), linii podkreślających krawędzie okładzin i tworzących dwa podłużne, puste pola (ryc. 4: 4), trzeci zdobiony jest grupą dookolnych żłobków różnej szerokości i głębokości umieszczoną na oprawce (ryc. 4: 8). Dwa egzemplarze zaopatrzono w ozdobną rękojeść. Pierwszy z nich (ryc. 4: I) posiada trzonek wykuty razem z głownią z jednego kęsa żelaza. Rękojeść jest profilowana, na końcu rozszerzona i wygięta do dołu w zoomorficzne zakończenie, przypominające kształtem zwierzęcą głowę. Drugi (ryc. 4: 2) zabytek charakteryzuje odlana z mosiądzu oprawka zdobiona na dwóch powierzchniach rękojeści wypukłym ornamentem kandelabrowym w postaci stylizowanego kwiatu lilii.

7 W tym opracowaniu pojęcie to, podobnie jak w pracy Moniki Kasprzak (2013: 31I), zostało rozszerzone również o metalową część rękojeści (porównaj Michalik 2007: 20). 
Druga kategoria obejmuje II przedmiotów (ryc. 4: I-3; 4:5-8; 5: 2, 3; 6: I; 9), zawierających $\mathrm{w}$ większości przypadków elementy o znaczeniu funkcjonalno-dekoracyjnym. W dwóch (ryc. 4: I, 5), ze względu na zastosowanie odmiennej techniki wykonania noży, cechy pierwotnie konstrukcyjne zostały pozbawione swego znaczenia. Pierwszym elementem jest nasada głowni o znaczeniu funkcjonalno-dekoracyjnym, zabezpieczająca oprawkę lub okładzinę przed przesuwaniem się. Ma ona różne formy: profilowanego, mosiężnego pierścienia o kolistym przekroju (ryc. 6: I), stożka (ryc. 4: 8), stożka z podstawą w kształcie czworokątnej płytki (ryc. 5: 2), stożka spłaszczonego bez podstawy (ryc. 4: 2, 6, 7; 9) lub z podstawą w kształcie pierścienia (ryc. 4: 3; 5: I), która może być ośmioboczna (ryc. 5: 3). W przypadku noży wykutych z jednego kęsa żelaza, mimo że przyjmuje podobne kształty stożka (ryc. 4: I) lub stożka z podstawą w kształcie czworokątnej płytki (ryc. 4: 5), stanowi rodzaj anachronizmu, który z uwagi na odmienną formę rękojeści nie pełni już funkcji zabezpieczającej. Kolejny element konstrukcyjno-dekoracyjny przybrał formę mosiężnego, odlewanego okucia trzpienia o kształcie stożkowatym (ryc. 4: 3; 5: 2, 3). Analogiczną część składową stwierdzono na nożu z Szafarni (Kasprzak 2013: 327, nr 2025). Zdaniem Przemysława Michalika (2007: 20) okucie pełni rolę konstrukcyjną gdy spaja obie okładziny. Wydaje się, że w omawianym przypadku okucie jako ogranicznik oprawki (podobnie jak nasada głowni) ma też charakter utylitarny. W zbiorze reprezentowana jest również ta forma, ale wykonana w innej technologii. Stanowi ona integralną część, sporządzonej z jednego kęsa żelaza, rękojeści lub trzpienia (ryc. 4: 5, 7). W tym pierwszym przypadku (zwieńczenie rękojeści) jest to detal o wyłącznie dekoracyjnej funkcji (ryc. 4: 5). Innym zaobserwowanym sposobem wzmocnienia konstrukcji noża uniemożliwiającym przesuwanie się oprawek jest nałożenie na trzpień (kolec) blaszek mosiężnych (por.: Kasprzak 2013: 327, nr 22I). W przypadku jednego z egzemplarzy można przypuszczać, że pierwotnie znajdowały się one w obecnie pustej przestrzeni na trzpieniu (ryc. 4: 7).

\section{Znaki na nożach}

W polskiej literaturze szersze zainteresowanie tym problemem badawczym, w związku z opracowaniem zespołu noży z Pucka, wykazał Przemysław Michalik (2007: 73-78). Dla omawianych materiałów szczególnie istotne są natomiast prace Moniki Kasprzak (2013: 316-32I) oraz Alicji Gomoliszek (2016: 424-430), które prezentują i grupują znaki odkryte na nożach pozyskanych w trakcie gdańskich wykopalisk ${ }^{8}$. Tego typu podział został również dokonany dla 76 znaków stwierdzonych w zbiorze noży z placu Nowy Targ we Wrocławiu (Wieczorek-Kańczura,

\footnotetext{
8 Omówienie i zestawienie znaków wytwórców zamieszczono także w publikacji noży ze stoczni Lastadia (Jędrzejczak-Skutnik 2020: 413-417).
} 
Szajt 2018: 303, 304, 309, ryc. 200). Jeszcze bogatsza jest literatura zagraniczna zawierająca katalogi znaków na nożach europejskich (Marquardt 1997; Amme 2012), między innymi z Londynu (Cowgill i in. 1987: 17-24) czy Amsterdamu (Baart, Krook 1977: 325-337). W procesie znakowania żelaza stosowano puncę, czyli żelazny stempel (Tuchołka-Włodarska 1978: 77, przypis ı; Gomoliszek 2016: 424, 425). Wybite w ten sposób elementy są powszechnie interpretowane jako znaki wytwórców (Cowgill i in. 1987: 17; Folke, Holtman 1993: 45I za Gomoliszek 2016: 424; Michalik 2007: 73). W przeszłości sygnatura wiązała wyrób z warsztatem, w którym powstał, dzięki czemu możliwa była skuteczna kontrola jakości (Michalik 2007: 73).

W prezentowanym zbiorze znaki wytwórców wystąpiły na sześciu nożach (ryc. 4: I, 7; 5: I-3; 6: I; 7). Wszystkie sygnowane noże miały znaki na lewym płazie. Taką prawidłowość odnotowano też w materiałach z innych gdańskich (Trawicka 2010: IIO; Gdańsk w Europie... 2011: 30, 31, ryc. 16, 17; Kasprzak 2013: 32I; Gomoliszek 2016: 425; Trawicka 2018: 343; Jędrzejczak-Skutnik 2020: 414) oraz europejskich odkryć (Cowgill i in. 1987: 20; Folke, Holtmann 1993: 45 I za: Gomoliszek 2016: 425). Kwestia lokalizacji sygnatury stanowiła przedmiot badań Przemysława Michalika (2007: 77). Autor wskazywał na ewentualny wpływ procesu produkcyjnego, sposobu używania lub noszenia noża oraz aspekty dekoracyjne lub praktyczne. Osobiście optował za pierwszą hipotezą, wskazując, że dla praworęcznego nożownika łatwiejsze było wykonanie znaku na lewym płazie noża. Jednocześnie odniósł się jednak do opinii kowala Z.B. Gałeckiego, według którego, gdy sygnatura wybijana jest na przedmiocie swobodnie leżacym na kowadle, bez znaczenia jest to, na której stronie (on) leży (Michalik 2007: 77, przypis 586). Wspomniany kowal uznał, że podstawową kwestię stanowiła dobra widoczność
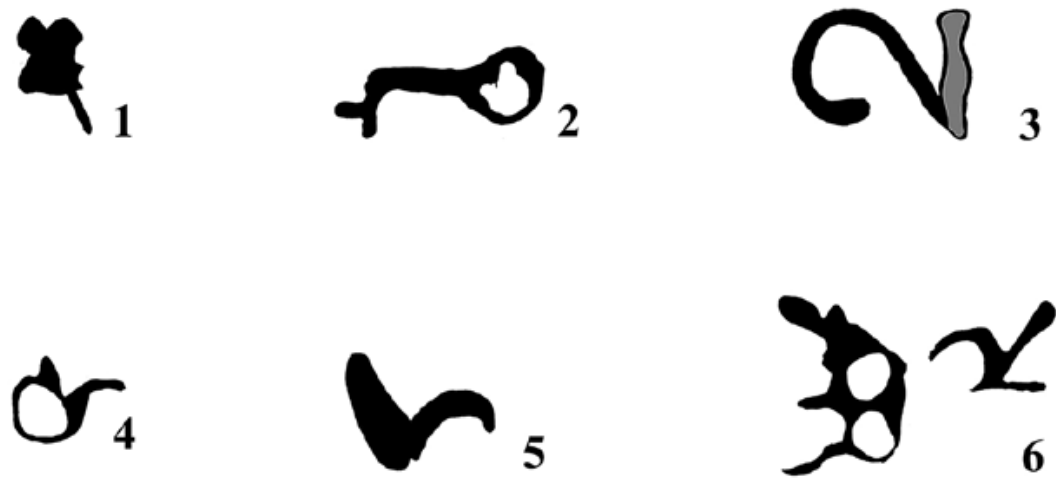

Ryc. 7. Znaki wytwórców wybite na nożach (rys. M. Wołyńska). 
znaku w trakcie używania noża. Zarówno podczas trzymania go w prawej dłoni, jak i odkładania przedmiotu eksponowany był jego lewy płaz. Ta interpretacja jest również najbardziej prawdopodobna dla Alicji Gomoliszek (2016: 425).

Znaki zarejestrowane na nożach pozyskanych ze stanowiska przy ulicy Wałowej 40 podzielono na sześć grup. Do wszystkich przypisano zaledwie jedną sygnaturę. Pośród rejestrowanych wyobrażeń można wydzielić znak w formie: elementu florystycznego (ryc. 5: 2; 7: I), przedmiotu związanego z życiem codziennym (ryc. 4: 7; 7: 2), cyfry (ryc. 6: 1; 7:3), symbolu solarnego(?) (ryc. 5: 1; 7: 4), litery(?) (ryc. 5: 3; 7: 5). Stwierdzono również sygnaturę złożoną, zawierającą trzy elementy (ryc. 4: I; 7: 6). Do pierwszej grupy zakwalifikowano motyw florystyczny w postaci czterolistnej koniczyny (ryc. 5: 2; 7: I). Znak interpretowany jako trójlistna koniczyna wystąpił na nożu nr 85, prezentowanym przez Alicję Gomoliszek (2016: 403, 428, 429, ryc. 85, I5I), a dwa elementy określone jako kwiat lub liść (cztery płatki/liście) na zabytku z Targu Siennego (Targ Sienny... 20I6: III, nr 188). Również wśród noży z placu Targ Nowy we Wrocławiu wskazano grupę znaków określonych jako trójliście (Wieczorek-Kańczura, Szajt 2018: 304, 309, ryc. 200, poz. 1879/II, I8Io/II, 296I/II). Natomiast element o formie zbliżonej do omawianej sygnatury został zinterpretowany jako krzyż (Wieczorek-Kańczura, Szajt 2018: 304, 309, ryc. 200, poz. 145I/II). Tego typu znak stwierdzono także na dwóch obiektach z Amsterdamu (Baart, Krook 1977: 326, 327, ryc. I19, I20). Do drugiej grupy zaliczono przedmiot codziennego użytku w postaci klucza (ryc. 4: 7; 7: I). Tego typu znaki wystąpiły również na nożach z badań przy ulicy Szafarnia i Długie Ogrody w Gdańsku (Kasprzak 2013: 317, 318, 319, ryc. 2:I 443, 2:2020) oraz jako element sygnatury złożonej amsterdamskiego egzemplarza (Baart, Krook 1977: 334, 335, ryc. 123). W następnej kategorii znalazła się cyfra 2 (ryc. 6: I; 7: 3). Słabo czytelna cyfra 8 była również wzmiankowana w zbiorze z badań przy ulicy Szafarnia i Długie Ogrody (Kasprzak 2013: 317, 319, ryc. 2:2023). Wydaje się jednak, że w tym przypadku jest to omawiany przez Przemysława Michalika (2007: 76), typowy dla miasta Steyr w Austrii, motyw połączonych dwóch kól. Do grupy czwartej przypisano okrąg z prostym oraz łukowatym wypustkiem, który przypomina symbol solarny(?) (ryc. 5: I; 7: 4). Jako tarcza słoneczna jest interpretowany znak z noża znalezionego przy ulicy Szafarnia i Długie Ogrody (Kasprzak 2013: 319, 320, ryc. 2:2035). Grupę piątą reprezentuje sygnatura w postaci nieokreślonego elementu nawiązującego kształtem do litery v (ryc. 5: 3; 7: 5). Zbliżony znak interpretowany jako złamany sierp został stwierdzony na nożu z zamku puckiego (Michalik 2007: 74, 75, ryc. 5:I.I). Obecne, ciemnożółte zabarwienie wskazuje zdaniem autora na pierwotne zalanie puncy płynnym stopem miedzi. Zabytek o ciekawej formie pozyskano z nawarstwień datowanych na drugą połowę XV w. Badacz nie znalazł analogi dla wspomnianego znaku, zbliżony, ale późniejszy o stulecie symbol odnotowano natomiast na liście nożowników krakowskich 
(Michalik 2007: 77, ryc. 10:2). W związku z powyższym zdaniem autora: Bardziej realna jest możliwość, że pochodzi on z warsztatu gdańskiego, elblaskiego lub toruńskiego..., nie wyklucza jednak proweniencji niemieckiej czy szwedzkiej. Te badania rzucają również nowe światło na ewentualne miejsce wyrobu noża ze stanowiska przy ulicy Wałowej 40 (ryc. 5: 3). Kolejna, szósta grupa zawiera znak trójelementowy. Składa się z motywu pary połączonych kół, któremu towarzyszy majuskuła $\mathrm{R}$ (ryc. 4: I; 7: 6). O rozbudowanej sygnaturze z zastosowaniem motywu połączonych kół, typowego dla miasta Steyr, wspominał Przemysław Michalik (2007: 76, ryc. Io.I). Znaki w formie koła lub kół wystąpiły również na nożach ze stanowiska Chmielna 73-74 (Gomoliszek 2016: 427, 428, ryc. 150: 29, 61, 63), natomiast połączenie tych elementów stwierdzono na nożu ze stanowiska przy ulicy Szafarnia, Długie Ogrody (Kasprzak 2013: 319, ryc. 2:2023).

Liczba sygnowanych noży odkrytych podczas wcześniejszych gdańskich badań była różna. W wypadku zabytków z Wyspy Spichrzów stanowiły one $52 \%$ zbioru (Jędrzejczak 2004: 35 za Kasprzak 2013: 317). Natomiast w zestawie ze stanowiska przy ulicy Szafarnia i Długie Ogrodu' było to tylko 26\% ogółu (Kasprzak 20I3: 317). Podobnie w przypadku zabytków z południowej części Wyspy Spichrzów, ze stanowiska przy ulicy Chmielnej $73-74^{10}$ znaki odnotowano na 34\% noży (Gomoliszek 2016: 425), a na pobliskiej Lastadii na 65\% zabytków z zachowanymi brzeszczotami (jest to $56 \%$ całego zespołu - Jędrzejczak-Skutnik 2020: 413 $)^{11}$. Natomiast w trakcie badań materiałów z jatek mięsnych ${ }^{12}$ do tej kategorii zakwalifikowano jedynie $7 \%$ egzemplarzy (Trawicka 2018: 343 ). Dla porównania sygnatury na nożach z placu Nowy $\operatorname{Targ}^{13}$ we Wrocławiu stwierdzono na głowniach $76 \mathrm{z} 483$ egzemplarzy. Wskazana kwestia dotyczyła więc $17 \%$ obiektów (Wieczorek-Kańczura, Szajt 2018: 296). W przypadku omawianego zbioru noży stołowych i kuchennych, egzemplarze sygnowane stanowią $46 \%$ ogółu (w całym zestawie - łącznie z nożami osobistymi jest to $48 \%$ ogółu). Należy jednak

9 Teren badań to $3860 \mathrm{~m}^{2}$ (Krzywdziński 2013: 23). Z tego obszaru, biorąc pod uwagę wielkość stanowisk, pozyskano 5 razy tyle noży (Kasprzak 2013: 309) co z ulicy Wałowej 40.

10 Wykopaliska objęły obszar około $9967 \mathrm{~m}^{2}$ (Krzywdziński 2016: 7). Porównując areały stanowisk, noży przy ulicy Chmielnej 73-74 jest o 70\% więcej niż przy Wałowej 40.

11 Badania szerokoprzestrzenne przeprowadzone w 2004 r. objęły teren o powierzchni $3000 \mathrm{~m}^{2}$ (Ignasiak 2020: 87). Odkryty zbiór, biorąc pod uwagę obszar stanowisk, jest prawie 16-krotnie większy niż ten z ulicy Wałowej 40 w Gdańsku.

12 Zachodznia część wykopu to $745 \mathrm{~m}^{2}$ (Krzywdziński 2018: 13). Liczba I52 noży (Trawicka 2018: 342) pozyskana z czterokrotnie mniejszego obszaru sprawia, że zbiór ten jest 26-krotnie większy niż grupa noży z Wałowej 40.

13 Teren badań objął około $4000 \mathrm{~m}^{2}$ (Mackiewicz i in. 2014: 168). Odkryty zbiór, biorąc pod uwagę obszar stanowisk, jest prawie 16-krotnie większy niż ten z ulicy Wałowej 40 w Gdańsku. 
zauważyć, że w przywoływanych zbiorach pozyskanych z innych gdańskich badań liczba zabytków oscylowała w granicach I3I-I66 sztuk (Jędrzejczak 2004: 35 za Kasprzak 2013: 317; Kasprzak 2013: 309; Gomoliszek 2016: 377; Trawicka 2018: 342) po wyjątkowo 360 egzemplarzy odkrytych na Lastadii (Jędrzejczak-Skutnik 2020: 40I), podczas gdy z ulicy Wałowej 40 pochodzą zaledwie 23 noże, w tym I3 związanych z gotowaniem oraz konsumpcją ${ }^{14}$. W opinii badaczy mały odsetek znakowanych noży z polskich, w tym gdańskich badań jest nieproporcjonalny do danych europejskich (Gomoliszek 2016: 429). Można przypuszczać, że ich liczba jest znacząco zaniżona, z uwagi na stan zachowania noży, a nie brak respektu dla uchwał cechu (Historia Gdańska 1982: 185; Gomoliszek 2016: 429). W tym przypadku poważny problem stwarzają nawarstwienia korozyjne, które skutecznie uniemożliwiają dostrzeżenie lub w najlepszym przypadku identyfikację sygnatury (Gomoliszek 2016: 430; Trawicka 2018: 343; Jędrzejczak-Skutnik 2020: 413).

Jeden z prezentowanych znaków był inkrustowany (ryc. 6: I; 7: 3). Wykonane z mosiądzu wypełnienie zachowało się fragmentarycznie. Przykłady takiego wzbogacenia sygnatury znane są również z innych gdańskich stanowisk (Jędrzejczak 2004: 36 za Kasprzak 2013: 317; Gdańsk w Europie... 2011: 30-31, ryc. 16-17; Kasprzak 2013: 318-321, ryc. 2:2018, 2:2040; Gomoliszek 2016: 378-380, 400, 430, ryc. 2, 3, 7, 76; Jędrzejczak-Skutnik 2020: 413), z Pucka (Michalik 2007: 69, ryc. 5:I.I, 34.I) czy Wrocławia (Wieczorek-Kańczura, Szajt 20r8: 309, ryc. 200). Na większą skalę zjawisko to reprezentowane jest w materiale zachodnioeuropejskim (Gomoliszek 2016: 430). Wydaje się, że omawiany przykład, z uwagi na częściowo zachowane wypełnienie wkute na zimno w wybity wcześniej znak (Cowgill $\mathrm{i}$ in. 1987: 24), stanowi wytlumaczenie dla znikomej liczby tego typu sygnatur. Zdaniem Alicji Gomoliszek (2016: 430) Być może noży zinkrustowanymi znakami byto więcej, ale mosiężne wypetnienie w trakcie użytkowania noża lub w wyniku procesów podepozycyjnych po prostu odpadto.

\section{Próba określenia funkcji noży}

Ten aspekt badań nad nożami stanowi kwestię sporną. Dla części archeologów budowa noży jest skorelowana z ich przeznaczeniem (Gomoliszek 2016: 430). Wskazuje się również na proporcje, a dokładnie mówiąc na długość rękojeści. W zależności od kształtowania się tej cechy nóż był używany od pozycji pionowej (przy krótkiej rękojeści) z wyłącznym zastosowaniem sztychu, po układ poziomy (przy dłuższej rękojeści), gdzie częścią pracującą stawało się całe ostrze (Cowgill

14 Brak informacji na temat wielkości terenu badań w sprawozdaniu z wykopalisk. Analiza danych z geoportalu (działka 434/15) oraz z Google Earth pozwala szacować, że przebadano obszar około $3000 \mathrm{~m}^{2}$. 
i in. 1987: 51; Gomoliszek 2016: 430; Trawicka 2018: 343). W opozycji do tego podejścia są badacze wrocławscy (Konczewska, Wachowski 20IO: 278), dla których bardzo różne użycie noży tylko częściowo znajduje odzwierciedlenie w ich formie.

Mimo nakreślonych problemów interpretacyjnych i ryzyka błędu, kolejni badacze, prezentując noże, odnoszą się do ich funkcji (Michalik 2007: 53-60; Kasprzak 2013: 321, 322; Gomoliszek 2016: 431-444). Model ten zostanie zastosowany również w tym opracowaniu, w celu wyodrębnienia przedmiotów używanych do przygotowania oraz spożywania posiłków.

\section{Noże stołowe}

Do tej grupy zaliczane są zabytki najmniejsze i najbardziej delikatne (Gomoliszek 2016: 43I), „o prostym tylcu i smukłym ostrzu zbiegającym się z nim w szpic” (Wieczorek-Kańczura, Szajt 20I8: 304, 309, ryc. 200, poz. I879/II, I8IO/II, 296I/II). Badacze zauważają, że cechy dystynktywne dla tej kategorii, takie jak niewielki rozmiar (Michalik 2007: 56) i wyjątkowe walory dekoracyjne (Cowgill i in. 1987: 52), sprawiły, że „sztućce do serwowania” były na stałe związane z gospodarstwem domowym (Michalik 2007: 53; Konczewska, Wachowski 2010: 278; Gomoliszek 20I6: 43I). Liczne ilustracje ich użycia stanowi XV- i XVI-wieczna ikonografia uczt $^{15}$. Natomiast w literaturze zarysowała się duża rozpiętość czasowa w określaniu momentu pojawienia się tego typu noży. Badacze wskazują okres od XIV po XVI w. (Wühr 196I: 32 za Gomoliszek 20I6: 43I; Haedecke 1981: 5 za Gomoliszek 2016: 431; Cowgill i in. 1987: 51).

W zbiorze z ulicy Wałowej 40 wydzielono grupę $\mathrm{I} 2$ noży stołowych (ryc. 4: I-8; 5: I-3; 6: I). Wśród nich zabytki niewielkie, łączone z początkiem funkcjonowania tej kategorii (ryc. 4: I-8), jak i większe, późniejsze egzemplarze (ryc. 5: I-3; 6: I). W pięciu przypadkach głownia zachowana jest fragmentarycznie (ryc. 4: 2-5; $5: 1$ ), w trzech brakuje oprawki rękojeści (ryc. 4: 6; 5:2,3). Generalnie prawie wszystkie z tych egzemplarzy charakteryzuje wąska głownia o maksymalnej szerokości płazu od 7 do $15 \mathrm{~mm}$, przy czym większość przypadków mieściła się pośrodku tego przedziału (porównaj Michalik 2007: 53, 54). Wyjątkiem są dwa większe noże. Jeden ma głownię o szerokości płazu $20 \mathrm{~mm}$ (ryc. 5: I), drugi $24 \mathrm{~mm}$ (ryc. 6: I).

Dwa z egzemplarzy zostały w całości wykute z jednego kęsa żelaza (ryc. 4: I, 5). Pierwszy (ryc. 4: I) ma uszkodzoną głownię, o zachowanej długości $58 \mathrm{~mm}$, przy szerokości płazu ıo mm i zoomorficznie zakończonej(?) rękojeści zaledwie $65 \mathrm{~mm}$

15 Nóż stołowy (Dieric Bouts Starszy, Święto Paschy, detal z Ottarza Eucharystii z Kościoła Świętego Piotra z Leuven, lata I 464-1467), https://www.wga.hu/frames-e.html?/html/b/ bouts/dirk_e/lastsupp/index.html [26 IX 202I]. Użycie noża stołowego (Gerard David, Wesele w Kanie, detal, około I500 r.; Musée de Louvre, Paryż), https://www.wga.hu/ht$\mathrm{ml} \_\mathrm{m} / \mathrm{d} / \mathrm{david} / 2 /$ cana_mas.html [26 IX 202I]. 
długości. Wykonany w ten sposób znacznie większy zabytek pozyskano ze stanowiska na Targu Siennym (Targ Sienny... 2016: 109). W tym przypadku na końcu rękojeści została wykuta stylizowana, zwierzęca głowa z rozwartym pyskiem. Przedmiot datowano na XV-XVI w. Prawdopodobnie także omawiany zabytek można łączyć z tym okresem. Kolejny z noży charakteryzuje równie krótka, ośmioboczna rękojeść (ryc. 4: 5), o długości $68 \mathrm{~mm}$. Dla tego przedmiotu nie udało się wskazać bezpośrednich analogii. W oparciu o kształt rękojeści (Baart, Krook 1977: 333 - poz. 636, 637; Kriegseisen 2015: 93, 102, ryc. I, I3) można go ostrożnie datować na okres XVI-XVII w.

W zbiorze noży stołowych zarejestrowano też egzemplarz z rękojeścią o długości $79 \mathrm{~mm}$, złożoną ze sztabki, do której przynitowano mosiężne okładziny (ryc. 4: 4). Nie zachowała się głownia przedmiotu, mimo to można wskazać analogie dla tego typu rękojeści. Pozbawiony tej części nóż o zbliżonym trzonku odkryto również w Amsterdamie (Baart, Krook 1977: 330 - poz. 624). Rękojeść tego egzemplarza składa się z dwóch mosiężnych okładzin łączonych ze sztabką trzema nitami. Zastosowany ornament $\mathrm{w}$ formie dwóch podłużnych, wypełnionych ukośnymi żłobkami pól stanowi rozwiniętą wersję zdobienia trzonka omawianego noża (ryc. 4: 4). Jednak odmiennie niż w gdańskim egzemplarzu rękojeść rozszerza się ku prosto ściętemu końcowi. Amsterdamska analogia datowana jest na drugą połowę XV w. (Baart, Krook 1977: 330). Według autorów w XV w. wytwórcy noży ozdabiali tego typu okładziny w rozmaity sposób, od prostych motywów po wyobrażenia całych scen (Baart, Krook 1977: 330). Tą bogatszą wersję reprezentują okładziny z ornamentem roślinnym, tworzące rękojeść zachowanego w całości, XVI-wiecznego noża odkrytego na Targu Siennym w Gdańsku (Targ Sienny... 2016: IIO, nr 187). Jest ona nieco krótsza (około $60 \mathrm{~mm}$ ) od prezentowanej i zwieńczona odlanym z mosiądzu okuciem, o wachlarzowatym kształcie, zdobionym motywem kratki. Biorąc pod uwagę fakt, że rękojeść noża z Wałowej (ryc. 4: 4) ma podobnie jak ta z Targu Siennego skute na płask zakończenie, można przypuszczać, że pierwotnie było ono zaopatrzone w ozdobne okucie. Wydaje się, że zabytek należy łączyć z końcem XV i XVI stuleciem.

W ośmiu przypadkach podstawę rękojeści stanowił trzpień, a w jednym sztabka przechodząca w trzpień. Do tej grupy należał prawdopodobnie najmniejszy z pozyskanych zabytków, o zachowanej długości $65 \mathrm{~mm}$ (ryc. 4: 2). Przy czym szerokość płazu jego głowni wynosi zaledwie $7 \mathrm{~mm}$, a przekrój rękojeści 4-5 x 6-8 mm. Jedyna w tym zbiorze rękojeść, w postaci odlanej z mosiądzu oprawki, zdobiona jest ornamentem kandelabrowym, charakterystycznym dla okresu renesansu oraz manieryzmu. Egzemplarz datowano na XVI w. Niewielkich rozmiarów jest również kolejny z zabytków (ryc. 4: 3), długość jego rękojeści to zaledwie $72 \mathrm{~mm}$, natomiast szerokość płazu mocno zniszczonej głowni wynosi $9 \mathrm{~mm}$. Oprawkę rękojeści o kształcie lekko rozszerzonego walca wykonano z poroża. Aspekt estetyczny 
nadaje jej fasetowanie w romby oraz wywiercone na zakończeniu koliste gniazda. Dwa artefakty o zbliżonej rękojeści pozyskano z twierdzy Bourtange w Holandii (Schans op de Grens... 1993: 544-545). Pierwszy (Schans op de Grens... 1993: 544, ryc. 29) zaopatrzono w oprawkę z kości słoniowej o kształcie i zdobieniu analogicznym do tej zastosowanej na nożu z Wałowej 40. Jednak w tym przypadku gniazda to prawdopodobnie cztery większe wgłębienia przedzielone przez cztery mniejsze, tworzące rodzaj czteropłatkowego kwiatu. Z opisu wynika, że w skład zabytku wchodzą żółte szklane oczka. Można przypuszczać (gdyż trudno potwierdzić to $z$ uwagi na stan ilustracji), że stanowiły one wypełnienie gniazd. Zabytek datowano na pierwszą połowę XVII w. Ten przykład potwierdzałby hipotezę, że kamienie lub szklane oczka stanowiły pierwotnie uzupełnienie ornamentu na nożu z Wałowej 40 (ryc. 4: 3). Drugi z noży został wykonany z tych samych materiałów, w analogicznej stylistyce (Schans op de Grens... 1993: 545, ryc. 30). O obecności na zakończeniu rękojeści gniazd (słabo widocznych na rycinie) świadczy informacja o żółtych szklanych oczkach. W niderlandzkim odpowiedniku, podobnie jak na omawianym egzemplarzu, trzpień wystaje poza oprawkę i jest zaopatrzony w stożkowate, mosiężne okucie. Chronologia tego noża została również wskazana na pierwszą ćwierć XVII w. Dla określenia ram czasowych użytkowania przedmiotów bardzo pomocna jest również ikonografia. Noże o zbliżonej rękojeści, choć większe, zostały przedstawione na martwych naturach Pietera Claesza ${ }^{16}$ i Adriaena Jansza Kraena ${ }^{17}$. Pierwszy obraz jest datowany na $1642 \mathrm{r}$. W przypadku drugiego brak takiej informacji, wiadomo jednak, że artysta działał od końca trzeciej dekady po schyłek lat siedemdziesiątych XVII w. W związku z powyższym omawiany zabytek można datować ramowo od końca XVI po pierwszą połowę XVII w.

Zbliżoną formę, lecz nieco większe rozmiary, prezentują kolejne trzy zabytki (ryc. 5: I-3). Wszystkie zaopatrzono w nasadę główni, w dwóch przypadkach porównywalną (ryc. 5: 1, 2) do tej z poprzednio omawianego przedmiotu (ryc. 4: 3). Dwa z nich mają również, tak jak wspomniany nóż, mosiężne okucie końca trzpienia (ryc. 5: 2, 3). Analogie dla dwóch z zabytków (ryc. 5: I, 2) może stanowić nóż stołowy z badań ratowniczych przy ulicy Kładki w Gdańsku. Ma on dwustronnie wyodrębniony sztych, profilowaną gałkę u nasady oraz znak wytwórcy wybity na lewym płazie. Przedmiot zaopatrzono w kościany, ukośnie żłobkowany trzonek, nasunięty na trzpień. Chronologię noża ustalono na XVII w. (Trawicka 2020a: 172). Odpowiednikiem omówionych powyżej artefaktów (ryc. 5: I-3) mogą

16 Nóż o fasetowanej rękojeści (Pieter Claesz, Martwa natura, 1642 r., kolekcja prywatna), https://www.wga.hu/frames-e.html?/html/c/claesz/roemer4.html [26 IX 202I].

17 Nóż o fasetowanej rękojeści (Adriaen Jansz Kraen, Martwa natura, kolekcja prywatna), https://www.wga.hu/html_m/k/kraen/banquet.html [26 IX 2021]. 
być obiekty prezentowane na XVII-wiecznych płótnach Pietera Claesza, Adriaena Jansza Kraena, Osiasa Beerta Starszego ${ }^{18}$ lub Georga Flegela ${ }^{19}$. Ukazują nam one noże o zbliżonych głowniach oraz dają wyobrażenie o przypuszczalnym wyglądzie niezachowanych rękojeści (ryc. 5: 2, 3).

Kolejne noże stołowe z trzpieniem rękojeści (ryc. 4: 6, 8) lub sztabką przechodzącą w trzpień (ryc. 4: 7) charakteryzuje zachowana prawie w całości wąska i smukła głownia o długości od 72 do $89 \mathrm{~mm}$. Szerokość płazów oscyluje w granicach II mm. Pierwszy z zabytków został pozbawiony oprawki (ryc. 4: 6). W dwóch kolejnych były one wykonane z drewna, kości lub poroża (ryc. 4: 7, 8), a ich długość nie przekraczała $80 \mathrm{~mm}$. Z uwagi na formę przedmiotów można je wstępnie datować na XVI w.

\section{Zestaw sztućców stołowych}

Wyą̧tkowymi obiektami są tworzące komplet: nóż (ryc. 6: I) i dwuzębnym widelec (ryc. 6: 2). Nóż to egzemplarz o dość masywnej, szerokiej głowni o długości I $46 \mathrm{~mm}$ i krótkiej rękojeści mierzącej $90 \mathrm{~mm}$, złożonej z kościanej, stożkowatej oprawki oraz nasady głowni w formie mosiężnego pierścienia. Widelec zaopatrzono w analogiczną, nieznacznie krótszą $(85 \mathrm{~mm}$ ) rękojeść. Informacji o tej kategorii zabytków dostarcza artykuł Jacka Kriegseisena (2015: 93-I04), prezentujący „Podróżny komplet sztućców wykonany przez Johanna Bartolomowicza - złotnika z Lidzbarka Warmińskiego". Tytułowy zestaw składał się z łyżki, czterozębnego widelca i noża (Kriegseisen 20I5: 94). Nakrycie o tej formie, przeznaczone dla każdego biesiadnika, stało się standardem w XVIII w. ${ }^{20}$ (Kriegseisena 20I5: IOI). Tego typu komplety zaopatrzone $w$ futerał ochronny pojawiły się jednak już około połowy XVI w. W okresie gdy sztućce dopiero zaistniały na stołach, stanowiły prawdopodobnie luksusowe prezenty ślubne ${ }^{21}$ (Kriegseisen 20I5: 103). W późniejszym

18 Ilustracja rekonstruowanej formy trzech z noży stołowych (ryc. 2: 1-3) (Osias Beert Starszy, Martwa natura z czereśniami i truskawkami w chińskich misach, 1608 r., Staatliche Mussen, Berlin), https://www.wga.hu/html_m/b/beert/elder/cherries.html [26 IX 2021].

19 Ilustracja rekonstruowanej formy trzech z noży stołowych (ryc. 5: I-3) (Georg Flegel, Martwa natura z czerésniami, 1635 r., Staatsgalerie, Stuttgart), https://www.wga.hu/html_m/f/flegel/ stil_che.html [26 IX 202I].

20 Por. podróżny komplet sztućców z futerałem z Augsburga, datowany na lata 1723-1735. Komplet złożony z: łyżki o owalnym czerpaku i płaskim, rozszerzonym trzonku, dwuzębnego widelca oraz noża o dł. $23 \mathrm{~cm}$ - Muzeum Narodowe w Warszawie (Bobrow 1998: 24).

21 Jacek Kriegseisen (2015: 103) pisze, że komplety sztućców pełniły funkcje osobistej zastawy stołowej, albo zestawów podróżnych. O podziale sztućców do serwowania na stacjonarne i przenośne-podróżne wspominają również badacze wrocławscy (Konczewska, Wachowski 20I0: 278). Dowód na istnienie tych ostatnich stanowią „znaleziska noży półmiskowych w skórzanych futerałach". 
okresie stały się tradycyjnymi suwenirami ofiarowanymi głównie jako podarunek chrzcielny (Kriegseisen 20I5: 104). Dwa komplety złożone z noży o bogato ornamentowanych trzonkach i zdobionych w identyczny sposób szpikulców, interpretowane jako stołowe, odkryto w latrynie seminarium nauczycielskiego w Rostoku (Burrows, Niemann 2000: 178, ryc. 7.5-6).Zdaniem Przemysława Michalika (2007: 52) Takie osobiste zestawy sztućców noszono przypięte do skórzanego lub też tekstylnego, na przyktad aksamitnego, pasa. WXV i XVI stuleciu w sktad kompletu wchodzić mogty dwa lub niekiedy nawet trzy noże różnej wielkości, ale też [...] szpikulce (Michalik 2007: 52 - przypis nr 443, 445). Zbliżoną, choć jednak znacznie bogatszą wersję gdańskiego zestawu stanowi komplet z londyńskiego muzeum Victorii i Alberta ${ }^{22}$. Pochodzące z Niderlandów zabytki są bardzo podobne zarówno pod względem formy, jak i zastosowanych materiałów. Rękojeść z bogato dekorowaną oprawką z kości słoniowej zaopatrzona jest w mosiężny pierścień. Czas powstania przedmiotów określono na lata 1680-1700, na XVII-wieczną metrykę gdańskiego zestawu może wskazywać również bogata ikonografia. Na datowanych na lata 1638, I669 i 1699 wyobrażeniach rzemieślników, pensjonariuszy fundacji Landauera ${ }^{23}$ i Mendla ${ }^{24}$, można prześledzić proces produkcji kompletu oraz zobaczyć jego ostateczną formę, analogiczną do prezentowanych zabytków. Zbliżone sztućce przedstawione w kontekście spożywania posiłku można natomiast podziwiać na Martwej naturze Georga Flegela z 1635 r. ${ }^{25}$

Podobnie interpretować oraz datować można zapewne drugi z widelców (ryc. 8) pozyskanych podczas badań na stanowisku przy Wałowej 40. Jest to również zabytek dwuzębny (dł. Iı $\mathrm{mm}$ ), zaopatrzony w trzpień o przekroju czworokątnym (dt. $43 \mathrm{~mm}$ ), lecz pozbawiony trzonka. Interesującą część stanowi ośmioboczna, stożkowata nasada widelca (dł. $32 \mathrm{~mm}$ ). Jej górny odcinek zdobiony jest rytym motywem jodełki, ze śladami pokrywania mosiądzem. Poniżej znajduje się oddzielona mosiężną kolistą blaszką podstawa okuta mosiądzem. Jej powierzchnię

22 Komplet sztućców z oprawkami z kości słoniowej, wykonany prawdopodobnie w Holandii, około 1680-1700 r. (Victoria \& Albert Museum, M.98\&A-1923), http://collections.vam. ac.uk/item/oring3/knife-and-fork-unknown/ [I IV 2019].

23 Wyrób kompletu sztućców - I638 r. (Hausbuch der Landauerschen... Bd. I: Amb. 279.2 ${ }^{\circ}$ Folio II3 verso), https://www.nuernberger-hausbuecher.de/75-Amb-2-279-II3-v [26 IX 202I].

24 Wyrób kompletu sztućców - 1669 r. (Hausbuch der Mendelschen... Bd. II: Amb. 317b.2 Folio 203 verso), https://www.nuernberger-hausbuecher.de/75-A mb-2-317b-203-v [26 IX 2021]. Komplet sztućców z futerałem - 1699 r. (Hausbuch der Mendelschen... Bd. II: Amb. 317 b. ${ }^{\circ}$ Folio 154 verso), https://www.nuernberger-hausbuecher.de/75-Amb-2-317b-I54-v [26 IX 2021].

25 Komplet sztućców (Georg Flegel, Martwa natura, około 1635 r., kolekcja prywatna), https://www.wga.hu/art/f/flegel/stil_oys.jpg [26 IX 202I]. 


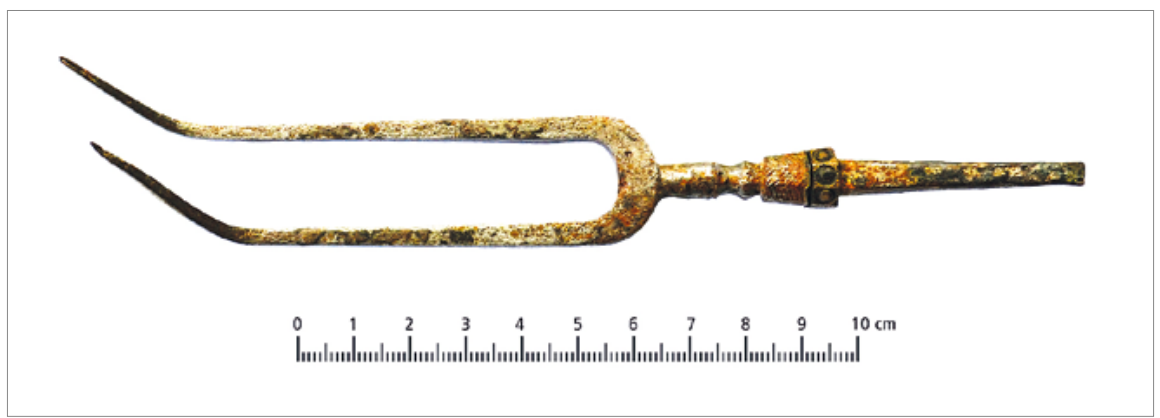

Ryc. 8. Widelec (fot. M. Wołyńska).

zdobią niewielkie, puncowane wgłębienia oraz sześć, prawdopodobnie szklanych kaboszonów. Osadzono je w gniazdach z mosiężnej blaszki, po trzy na stronie wierzchniej oraz spodniej widelca. Poniżej tej części nałożono na trzpień kolejną mosiężną blaszkę oddzielającą nasadę od niezachowanego trzonka. Tego typu dwuzębny, pozbawiony rękojeści widelec pozyskano podczas badań na grodzisku w Słoszewach (Grupa 2007: 433). Przedmiot posiada, zlokalizowane u nasady trzonka, trzy przewężenia na jego obwodzie, które stanowią element zdobniczy lub były zabezpieczeniem przed ściekającym sosem. Jest natomiast znacznie mniejszy: jego długość całkowita wynosi iı $7 \mathrm{~mm}$, a długość widełek $57 \mathrm{~mm}$. Słoszewy należały do Krzyżaków od 1392 r., a w I 4 I 4 r. zostały zniszczone przez wojska polskie. Widelec mógł zostać wykonany w miejscowej kuźni, a jego powstanie zamyka data I4I 4 r. (Grupa 2007: 433-435, ryc. I, przypis 2). Analogiczne, dwuzębne widelce pozyskano z fosy miejskiej we Wrocławiu ${ }^{26}$ (Wiśniewski 1993: 337, ryc. 3:n, o; Konczewska, Konczewski 2004: 97, 117-119, 172, 174, 175, ryc. 24 :f, 26:g, k, s, 27:b, h), z kontekstu o szerokich ramach chronologicznych obejmujących okres od drugiej połowy XIII po drugą połowę XIX w. (Wiśniewski 1993: 333; Konczewska, Konczewski 2004: 89). Rzadko zachowany trzonek w większości przypadków był prosty, w formie metalowej, drewnianej lub kościanej oprawki, czy złożony z okładzin kościanych lub drewianych (Konczewska, Konczewski 2004: 97, II7-II9, I7 I, I74, I75, ryc. 23:f, 24:f, 26:h, 27:f). Można jednak wskazać widelce z kościanymi lub rogowymi oprawkami tworzącymi bardziej dekoracyjne rękojeści (Wiśniewski 1993: 337, ryc. 3:n, o). Generalnie najliczniejszą i najbardziej zróżnicowaną grupę stanowiły widelce z trzpieniem rękojeści (Konczewska, Konczewski 2004: 97). Należy zwrócić uwagę, że podobnie jak w gdańskich egzemplarzach

26 Badania prowadzonych w latach 1998-1999 dostarczyły 29 widelców o różnym stopniu zachowania (Konczewska, Konczewski 2004: 97). 
(ryc. 6: 2; 8) w zabytkach z wrocławkiej fosy miejsce przejścia w trzpień lub sztabkę było podkreślone (wzmocnione) „pierścieniowatym lub dzwonowatym kolankiem” (Konczewska, Konczewski 2004: 97, 174, 175, ryc. 26:g, 27:a, c, d, f, h). Zdaniem autorów takie rozwiązanie oprócz zabezpieczenia przed ściekającym sosem mogło jednocześnie pełnić rolę elementu zdobniczego (Konczewska, Konczewski 2004: 97, 175, ryc. 27:b). Jeden widelec udało się również pozyskać z wrocławskiego placu Nowy Targ, jest on datowany szeroko na czasy nowożytne (Szajt 2018: 383, 388, ryc. 262). Dwuzębny egzemplarz, o wymiarach bardzo zbliżonych do wielkości gdańskich zabytków z ulicy Wałowej, charakteryzuje żelazny trzonek z drewnianą rękojeścią zakończona w górnej części skuwkalopaska wykonana z blachy cynowej. Zdaniem autora wielkość widelca może świadczyć o zastosowaniu jako sztućca półmiskowego (Szajt 2018: 383). Natomiast morfologia zabytku umożliwia datowanie ramowe na okres od końca XV po koniec XVII w. Dwuzębny widelec, $\mathrm{z}$ fragmentrycznie zachowaną sztabką rękojeści wchodził również w skład nowożynego depozytu przedmiotów metalowych z okolic Gliwic-Czechowic (Zdaniewicz 20I3: 4I2, 4I7, 4I8, ryc. 8.4). Zabytek tego typu pozyskano także podczas badań na obszarze dawnej kaplicy i cmentarza św. Jakuba w Stargardzie (Sil, Burdziej 2015: 394, 398, ryc. 27:2). W tym przypadku dwuzębny widelec posiadał rękojeść w formie sztabki z dwoma płytkami, które zamocowano przy użyciu trzech nitów żelaznych. Zabytek odkryto w nawarstwieniach datowanych na lata 1678-1736 i 1745/1746-1779 (Sil, Burdziej 2015: 394, 398, ryc. 27:2). Analogiczny przedmiot o drewnianej rękojeści, datowany na XVII w., pozyskano z twierdzy Bourtange w Holandii (Schans op de Grens... 1993: 553, ryc. 79).

Widelcem posługiwano się już sporadycznie we wczesnośredniowiecznej Europie. W tym okresie sztućce tego typu były używane rzadko przez elity. Nieliczne wzmianki o widelcu pojawiają się w XIV- i XV-wiecznych kronikach, ale jego rola wzrasta w późnym średniowieczu. Potwierdzają to zapisy testamentowe oraz ikonografia (Grupa 2007: 434; Szajt 2018: 384, 385, 388, ryc. 263). Rozpowszechnienie się widelca w Europie nastąpiło jednak dopiero w drugiej połowie XVI w. W tym okresie uczta stała się elementem życia intelektualnego, co skierowało uwagę na estetykę jedzenia. Widelec był też niezbędny z uwagi na modę. Jego używanie zapobiegało poplamieniu szerokich kryz noszonych na szyi. Na podstawie licznych kronikarskich wzmianek i zapisów inwentarzowych można też wnosić, że w XVI w. widelec był w użyciu również w Polsce (Bobrow 1998: 8). Jednak analiza publikacji dotyczących historii zastawy stołu dokonana przez Jakuba Szajta (2018: $384,385)$ doprowadziła autora do wniosku, że: użycie widelca jako sztućca indywidualnego upowszechnito się w szerszym gronie spoteczeństwa relatywnie późno, dopiero wXVIII w., choćnawet wówczas nie byt on narzędziem tak popularnym jak obecnie.

Prezentowane dwuzębne okazy są typowe dla XVI-XVII w. (Konczewska, Konczewski 2004: 97). W związku z tym wydaje się, że również drugi z omawianych 
zabytków można łączyć z XVII stuleciem. O wadze tego odkrycia może świadczyć fakt, że ten przedmiot rzadko pojawiał się w wyposażeniach domów mieszczańskich. Widelec określany jako widełki lub grabki wspominany był jedynie przy opisach stołów magnackich i królewskich ${ }^{27}$. Natomiast jego funkcja była prawdopodobnie ograniczona do nabierania z mis lub półmisków na talerze (Historia kultury materialnej... 1978: 318; Schans op de Grens... 1993: 553).

\section{Noże kuchenne}

Do kategorii noży kuchennych należy zaliczyć obiekty największe, przeważnie o masywnych trzonkach i głowniach. Inne kryterium stanowi ich prosta forma i brak zdobienia. Dane metryczne nie są w tym przypadku cechą ułatwiającą interpretację, z uwagi na znaczą różnorodność tej grupy (Michalik 2007: 56). Zbliżone budową noże mogły być używane zarówno w kuchni, jak i w jatkach mięsnych. W jednym i drugim przypadku praca wiązała się z ćwiartowaniem mięsa (Gomoliszek 2016: 44I, 442). Być może ze względu na tę kwestię Ewa Trawicka (2018: 342) w opracowaniu noży z jatek mięsnych w Gdańsku stwierdza: $Z$ uwagi na specyfikę stanowiska nie powinien dziwić fakt, że znaleziska te sa tak liczne. Trudno natomiast ustalić funkcje poszczególnych egzemplarzy i jednoznacznie wskazać, które mogty być wykorzystywane przy obróbce mięsa w kramach. Badaczka wskazuje przy tym na uniwersalność średniowiecznych noży.

$\mathrm{Na}$ stanowisku przy Wałowej 40 pozyskano jeden egzemplarz, który można łączyć z tą kategorią (ryc. 9). Jest to nóż o zachowanej długości ponad $200 \mathrm{~mm}$, ze sztabką rękojeści oraz uszkodzoną, pozbawioną sztychu głownią. Stąd, na podstawie widocznej części można jedynie przypuszczać, że ostrze było prawdopodobnie lekko skośne ${ }^{28}$. Rękojeść składa się z nasady głowni o formie spłaszczonego stożka, która przechodzi w sztabkę rozszerzającą się silnie w kierunku ułamanego zakończenia. Od strony nasady widoczne są częściowo zachowane dwie płytki z poroża (z widoczną korą) mocowane pierwotnie na dwa nity. Można przypuszczać, że nóż był dość masywny, ponieważ zachowana szerokość rękojeści wynosi 3I mm. Jako analogię można wskazać nóż kuchenny z badań przy ulicach Szafarnia i Długie Ogrody w Gdańsku (Kasprzak 2013: 321, 325, nr 1448). Zabytek ma długość zbliżoną do omawianego obiektu, charakteryzuje go również lukowate ostrze oraz sztabka rekojeści. Jego chronologię określono na XVI-XVIII w. Drugi okaz, wręcz

$27 \mathrm{Na}$ ekskluzywny charakter tej kategorii przedmiotów wskazują również badacze niderlandzcy (Schans op de Grens... 1993: 553). Potwierdzeniem tej tezy miała być ograniczona liczba tego typu przedmiotów odkryta w twierdzy Bourtange, co korelowałoby ze statusem społecznym jej mieszkańców złożonych z żołnierzy oraz ich rodzin.

$28 \mathrm{Z}$ uwagi na stan zachowania noża trudno w tym przypadku odnieść się do obserwacji Przemysława Michalika (2007: 58, 59), który nożom kuchennym przypisuje półokrągłą linię ostrza. 

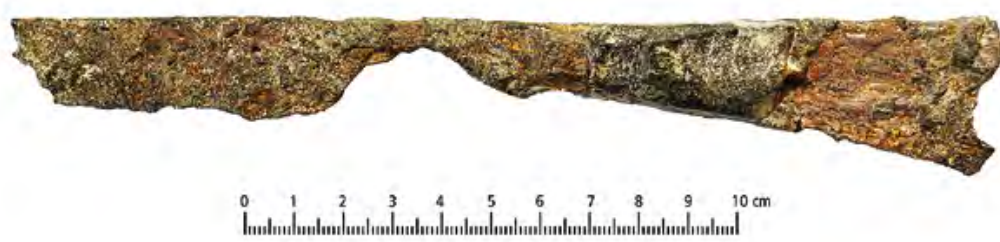

Ryc. 9. Nóż kuchenny ze sztabką (fot. M. Wołyńska).

bliźniaczy do egzemplarza z Szafarnii, pochodzi ze stanowiska przy Chmielnej 73-74 (Gomoliszek 2016: 395, ryc. 57). Autorka datuje go na okres od końca XIV po pierwszą połowę XVI w.

Noże kuchenne znane są również z wyobrażeń ikonograficznych. Bezcenne dzieło stanowi manuskrypt z końca XIV w. znany jako Tacuinum Sanitatis lub Theatrum Sanitatis, będący średniowiecznym kompendium wiedzy (Hoeniger 2006: 52-82; Gomoliszek 2016: 442). Omawianą grupę zabytków, w niezmienionej formie, widzimy również na płótnie Passerottiego z końca XVI w. ${ }^{29} \mathrm{~W}$ świetle powyższych rozważań prezentowany nóż kuchenny (ryc. 9) można datować ramowo na okres XVI-XVII w.

\section{Kontekst pozyskania}

Noże odkryte na stanowisku przy ulicy Wałowej 40 pochodzą z nawarstwień wtórnych, datowanych od drugiej połowy XVI po XVIII w. Należy do nich warstwa niwelacyjna wału o chronologii określonej na okres od drugiej połowy Xv I po połowę XVII w., czy łączone z drugą połową tego stulecia zasypisko fosy (ryc. 4: 5, 7; 5: 3). Akcja niwelacji wynikała z notowanych na lata 40. XVII w. przekształceń polegających na wznoszeniu nowych ziemnych fortyfikacji bastionowych. Późniejsze zagospodarowanie omawianego terenu przebiegało bardzo wolno. $\mathrm{Na}$ planie z 1778 r. odnotowano zabudowę jedynie na obu pierzejach nowego odcinka Rybaków Górnych (Jagiełło 2017: 3, 4). Ze stopniowym zasiedleniem tego obszaru należy zapewne łączyć datowaną na XVII w. oraz dwie łączone z XVIII stuleciem studnie. $Z$ wypełniska pierwszej pochodzi komplet złożony z noża i widelca (ryc. 6: I, 2), a z kolejnych łącznie osiem noży i jeden widelec (ryc. 4: I, 2, $3,6,8 ; 5: 1,2 ; 8 ; 9)$.

29 Bartolomeo Passerotti, Kram rzeźników, 1580 r. (Galleria Nazionale d'Arte Antica, Rome), https://www.wga.hu/html_m/p/passerot/butcher.html [26 IX 202I]. 


\section{Proweniencja}

Można założyć, podobnie jak Alicja Gomoliszek (2016: 445), że większość z pozyskanych zabytków była dziełem miejscowych nożowników. Ich cech jest potwierdzony w Gdańsku już w XIV w. (Bogucka 1962: 107; Historia Gdańska 1978: 445). Produkcja bazowała na żelazie uzyskiwanym ze szwedzkiego osmundu w miejscowych kuźnicach (Historia Gdańska 1982: 198). Proces wykonania noża zaczynano od kucia, następnie szlifowano, ostrzono i oprawiano. Aby zwizualizować pracę tej grupy rzemieślników, można posiłkować się pochodzącymi z Ksiąg Domowych portretami pensjonariuszy norymberskich domów spokojnej starości fundacji Mendla i Landauera ${ }^{30}$. Należy zaznaczyć, że część prac związanych z otrzymaniem noża była wykonywana poza warsztatem nożownika. I tak szlifować można było samodzielnie za pomocą różnej grubości pilnika lub w profesjonalnej szlifiernii (Gomoliszek 2oı6: 446, 448). Natomiast ostrzenie noży zapewniały wyposażone w specjalne kamienie slofarnie, warsztaty wzmiankowane od połowy XIV w. (Bogucka 1962: 107). Następny krok stanowiło mocowanie okładzin lub oprawek, ich polerowanie i umieszczenie okuć oraz skuwek (Michalik 2007: 39-4I). Ta kolejność pozwalała na uniknięcie zniszczenia rekojeści (Michalik 2007: 37).

W prezentowanym zbiorze noży stołowych i kuchennych stwierdzono oprawki lub okładziny kościane lub rogowe $(3 \mathrm{I} \%)^{31}$. Zarejestrowano również identyczną częstotliwość (31\%) zastosowania rękojeści metalowych ${ }^{32}$, w tym połowę stanowiły mosiężne $(15 \%)^{33}$. W mniejszym stopniu wykorzystano drewno $(15 \%)^{34}$, co jest ewenementem w Gdańsku, gdyż ten rodzaj oprawy dominuje (Kasprzak 20ı3: 313, 314; Gomoliszek 2016: 448). Natomiast na stanowisku przy ulicy Chmielnej 73-74 odnotowano identyczny procentowo jak przy ulicy Wałowej 40 udział opraw z kości lub poroża, natomiast z mosiądzu dwa razy większy (Gomoliszek 20ı6: 448). Być może na taki obraz analizowanego materiału wpływa wspominana już mała, więc mniej miarodajna liczba elementów zbioru oraz słaby stan zachowania rękojeści.

Zdaniem Przemysława Michalika (2007: 39) powszechne stosowanie głównie rękojeści drewnianych wynikało z większej dostępności surowca, a tego typu rękojeść mogła być z powodzeniem wykonywana przez nożowników. Natomiast bardziej skomplikowana obróbka kości i poroża była zostawiana specjalistom.

30 Warsztat wytwórcy noży, 1565 r. (Hausbuch der Mendelschen... Bd. II: Amb. 317 b. $2^{\circ}$ Folio 17 verso).

31 Natomiast w całym zestawie noży z tego stanowiska jest to $42 \%$.

32 Natomiast w całym zestawie noży z tego stanowiska jest to $42 \%$.

зз Natomiast w całym zestawie noży z tego stanowiska jest to $17 \%$.

34 Natomiast w całym zestawie noży z tego stanowiska jest to $17 \%$. 
Ten pogląd w pewnym stopniu podważa ikonografia dostarczająca przedstawień zarówno wytwórców rękojeści drewnianych, jak i rogowych ${ }^{35}$.

Niewątpliwie przedstawiciele cechu nożowników musieli liczyć się z konkurencją. Należeli do niej znajdujący się poza ramami organizacji partacze zamieszkujący obrzeża miasta (Bogucka 1962: 300, 302). Jednocześnie na rynek gdański trafiały wyroby importowane (Bogucka 1962: 22I, 222). Problem proweniencji noży był już poruszany przy okazji omawiania znaków wytwórców. W jednym przypadku wskazano znak zawierający motyw połączonych kół (ryc. 4: I), typowy dla nożowników z miasta Steyr w Austrii (Michalik 2007: 76, ryc. Io.I). Z uwagi na duże podobieństwo do zabytków niderlandzkich (Schans op de Grens... 1993: 544,545 , ryc. 29, 30) zastanawiające jest miejsce powstania noża o fasetowanej, wykonanej z poroża rękojeści (ryc. 4: 3). Jednak nie zawsze musi to być import. Należy się także liczyć z obecnością obcych rzemieślników, którzy wprowadzali swoje własne wzorce na gdański rynek (Bogucka 1962: 302; Gomoliszek 2016: 449).

Szansą na lepsze rozpoznanie tych kwestii jest publikacja licznych, nieopracowanych dotychczas artefaktów. Porównanie jak największej liczby gdańskich noży stworzy okazję do trafniejszych obserwacji pewnych prawidłowości i pozwoli na rozbudowanie wiedzy, także w zakresie znaków wytwórców (Gomoliszek 20ı 6: 449, 450).

\section{Analiza łyżek stołowych i kuchennych}

Łyżki stołowe

\section{Stan zachowania}

Pośród I 4 łyżek stołowych z ulicy Wałowej 40 zaledwie cztery zachowały się w całości (ryc. IO: 3; II: 5, 7; 13). Kolejne trzy egzemplarze przedstawiały stan odbiegający od pierwotnego (ryc. IO: I, 2; II: 3; I2), uszkodzenia cechował różny stopień zniszczenia czerpaka. W pozostałych przypadkach stwierdzono wyłącznie obecność czerpaka (ryc. IO: 4, 5) bądź trzonka (ryc. II: I, 2, 4, 6).

\section{Formy}

W prezentowanym zbiorze można wskazać pięć typów łyżek, które odróżnia kształt czerpaka oraz forma trzonka. Cechy różnicujące to: przekrój, wygląd nasady i końca.

35 Produkcja drewnianych okładzin do noża - 1588 r. (Hausbuch der Landauerschen... Bd. I: Amb. $279.2^{\circ}$ Folio 6I recto), https://www.nuernberger-hausbuecher.de/75-Amb-2-279-6I-r [26 IX 2021]. Produkcja rogowych okładzin do noża - 1687 r. (Hausbuch der Mendelschen... Bd. II: Amb. 317 b. $2^{\circ}$ Folio 182 verso), https://www.nuernberger-hausbuecher.de/75-Amb$-2-317 b-182-v[26$ IX 202I]. 


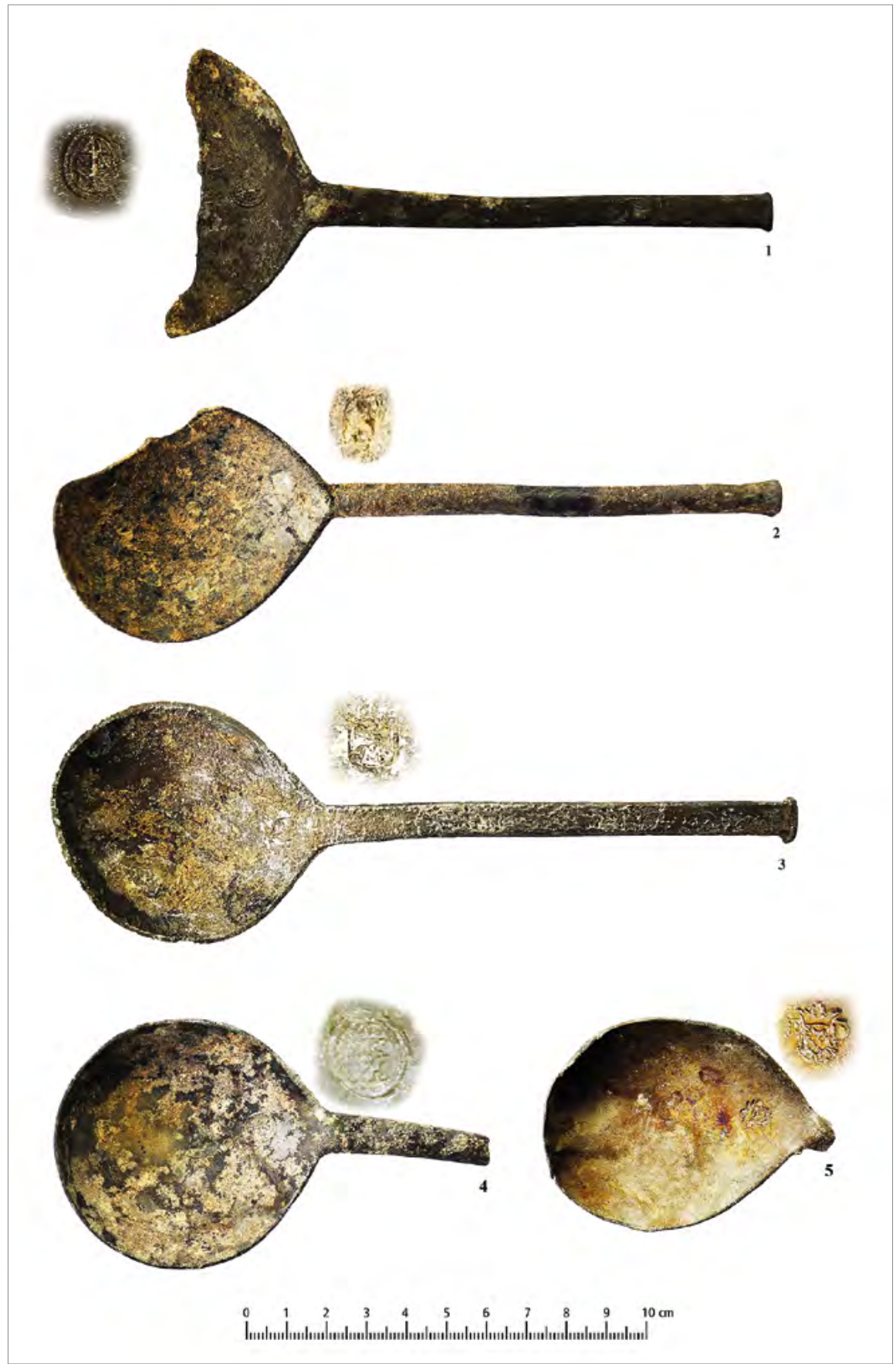

Ryc. 10. Łyżki stołowe cynowe typ I (fot. M. Wołyńska). 


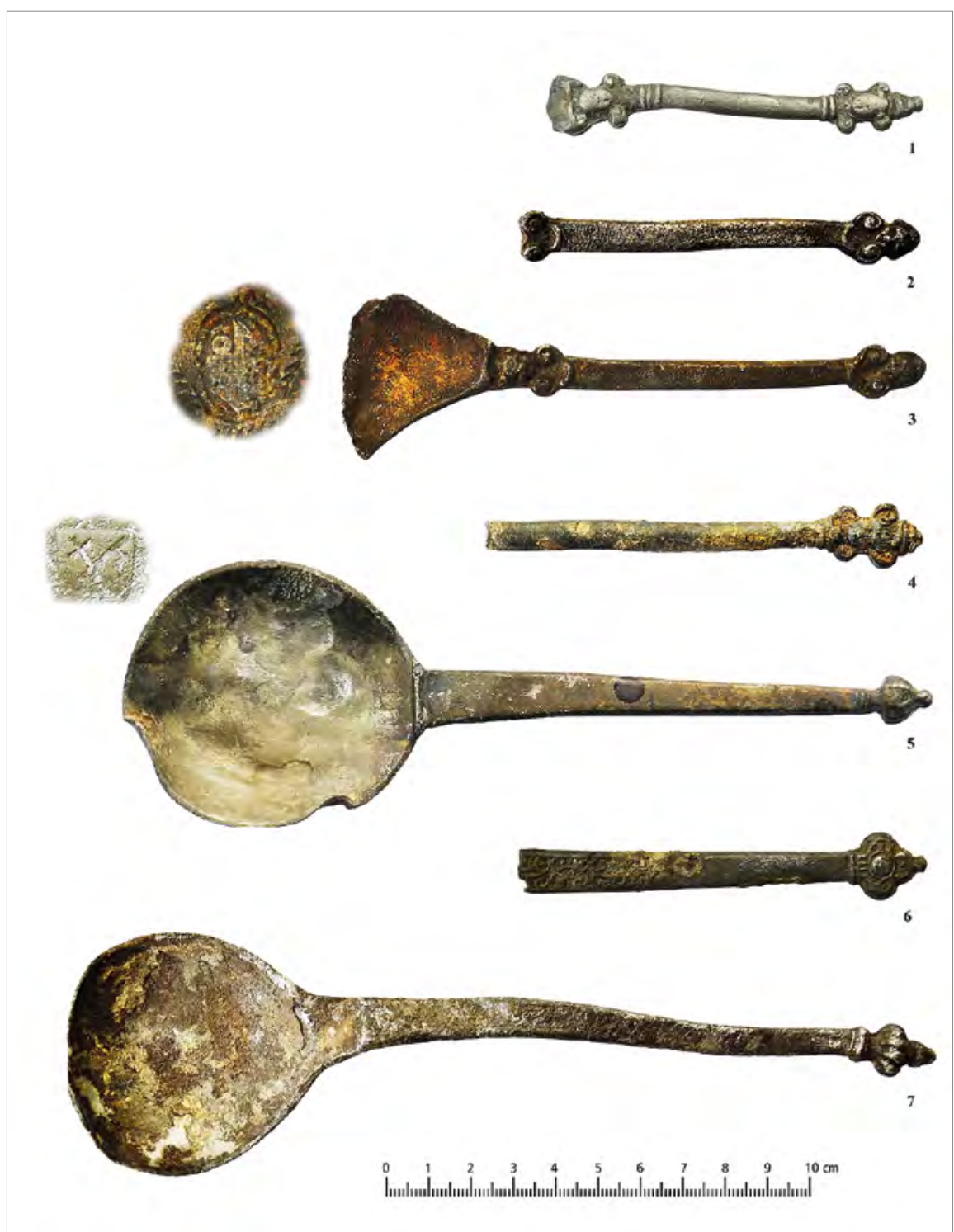

Ryc. 11. Łyżki stołowe cynowe typ II: I-4, typ III: 5-7 (fot. M. Wołyńska).

Pierwszy typ charakteryzują gruszkowate czerpaki (ryc. IO: I-5) oraz proste trzonki o przekroju owalnym (ryc. Io: 5) bądź sześciogrannym (ryc. IO: 4). W przypadku egzemplarzy o całkowicie zachowanych trzonkach, zarówno o przekroju owalnym (ryc. Io: 2), jak i sześciogrannym (ryc. ıо: I, 3), zaobserwowano końce rozszerzone stożkowato i prosto ścięte. Łyżki osiągają długość około I80 mm 
(I०: 2, 3), w tym długość czerpaków to około $65 \mathrm{~mm}$, przy szerokości około $60 \mathrm{~mm}$ (IO: 2-5). Trzonki mają długość od III do $117 \mathrm{~mm}$, przy szerokości 8-II i grubości 4-6-9 mm (ryc. Io: I-3). Dla tej grupy doskonałą analogię stanowią wykazujące powyższe cechy dwie XVII-wieczne łyżki ze zbiorów Muzeum Narodowego w Gdańsku (Tuchołka-Włodarska 1992: I04 - poz. 78, I08 - poz. 83). Zabytki ze stanowiska przy Wałowej 40 pochodzą ze studni datowanej na XVIII w. Biorąc jednak pod uwagę analogie oraz kontekst pozyskania, można je datować na XVII stulecie.

Typ drugi reprezentują łyżki, z których zachowały się głównie trzonki (ryc. II: I, 2, 4). Tylko w jednym przypadku stwierdzono także fragment czerpaka (ryc. II: 3). Omawiane egzemplarze mają trzonki w przekroju sześciogranne (ryc. II: 2, 3) bądź owalne (ryc. II: I, 4). W każdym z tych przypadków bardzo charakterystyczną cechę stanowi jednak plastyczne zdobienie, które wpływa bezpośrednio na formę przedmiotu. Jest ono zlokalizowane przeważnie na stronie wierzchniej u nasady oraz w zakończeniu trzonka i ma postać maszkarona podkreślonego od spodu wolutą (ryc. II: 2-4). Na jednym z egzemplarzy ornament wykonano obustronnie (ryc. II: I), a na dwóch zabytkach jest zachowany fragmentarycznie (ryc. II: 2, 4). Zdobienie wystąpiło również w wersji wzbogaconej o koniec $\mathrm{w}$ formie profilowanego stożka, oraz umieszczonych na trzonku (przy maszkaronach) grup dookolnych oraz niedookolnych listew (ryc. II: I, 4). Długość trzonków oscyluje w granicach 87-102 mm, szerokosś 6-16 mm, a ich grubość wynosi $4-8 \mathrm{~mm}$. Ten typ, z uwagi na dużą częstotliwość występowania łyżek dekorowanych motywem maszkarona w materiałach pochodzących z Gdańska, został przez Barbarę Tuchołkę-Włodarską (1992: 20) przypisany warsztatom gdańskim. Doskonałą analogią dla dwóch zabytków (ryc. II: I, 4), pozwalającą na odtworzenie ich pierwotnej formy, jest datowana na XVII w. łyżka ze zbiorów Muzeum Narodowego w Gdańsku. Według Tuchołki-Włodarskiej (1992: 20, 106, ryc. 80) widoczny na niej „manierystyczny motyw maski z dwiema wolutami” stanowi odwzorowanie łyżek srebrnych. Prezentowane przedmioty pochodzą ze studni datowanej na XVIII w. Biorąc pod uwagę analogie oraz kontekst pozyskania, można datować je na XVII stulecie.

W skład grupy trzeciej wchodzą łyżki o czerpaku gruszkowatym (ryc. II: 7) lub lekko kolistym (ryc. II: 5). Ich trzonki mają przekrój sześciogranny, są szerokie u nasady i mocno zwężają się ku końcowi w formie płaskiego trójpłatkowego kwiatu, zwieńczonego kulistym wypustkiem (ryc. II: 6) bądź profilowanej (ryc. II: 5) lub kanelowanej gałki (ryc. II: 7). Długość całkowita przedmiotów wynosi od I87 do $207 \mathrm{~mm}$, czerpaki osiągają długość $65-73 \mathrm{~mm}$ przy szerokości 57-6I mm, a trzonki długość I22-I34 mm, przy szerokości 6-I3 $\mathrm{mm}$ i grubości 3-II $\mathrm{mm}$. Odpowiedników dla dwóch z zabytków (ryc. II: 5, 7) można szukać w zbiorach Muzeum Narodowego w Gdańsku. Pierwszy (ryc. II: 5) nawiązuje formą do wiązanej 
z gdańskim warsztatem łyżki z drugiej ćwierci XVII w. (Tuchołka-Włodarska 1992: IO5 - poz. 79). Trudno jednak wypowiadać się o jego proweniencji (poniżej). W przypadku drugiego należy zwrócić uwagę na charakterystyczne zakończenie w formie kanelowanej gałki (ryc. II: 7). Ten sposób zdobienia wystąpił na kilku egzemplarzach ze wspomnianej powyżej kolekcji (Tuchołka-Włodarska 1992: I03 - poz. 76 i 77, II2 - poz. 87, II3 - poz. 88, II5 - poz. 90). Pod względem formy i lokalizacji elementu dekoracyjnego najbliższy jest egzemplarz XVII-wieczny (Tuchołka-Włodarska 1992: 103 - poz. 77). Natomiast sam kształt gałki analizowanego zabytku jest bliższy zakończeniu XVIII-wiecznej łyżki łączonej z gdańskim warsztatem (Tuchołka-Włodarska I992: II5 - poz.90). Łyżka o podobnie uformowanym końcu została również uwieczniona na martwej naturze Cornelis’a Mahu, datowanej na lata 30. XVII w. ${ }^{36}$ Analogię dla kolejnego zabytku (ryc. II: 6) można wskazać pośród materiałów pozyskanych z fosy miejskiej we Wrocławiu. Odkryta łyżka jest zachowana w całości i ma trzonek identyczny (Wiśniewski 1993: 339, ryc. 4:f) jak prezentowany zabytek (ryc. II: 6). Na jej czerepie widoczny jest znak wytwórcy w formie róży Tudorów pod koroną otwartą z umieszczonymi po bokach, nieczytelnymi literami monogramu. Niestety, przedmiot pochodzi z kontekstu o szerokich ramach chronologicznych obejmujących okres od drugiej połowy XIII w. po drugą połowę XIX w. (Wiśniewski 1993: 333). Prezentowane artefakty wydobyto ze studni datowanej na XVIII w. Biorąc pod uwagę analogie oraz kontekst pozyskania, można datować je na XVII stulecie.

Czwarty typ prezentuje jeden zabytek (ryc. I2). Przedmiot odróżnia materiał, z którego został wykonany - zastosowano tu żelazo, uszlachetnione przez pokrycie warstwą cyny (słabo zachowaną). Czerpak łyżki jest częściowo uszkodzony, gruszkowaty, natomiast trzonek, tuż za nasadą wygięty pod kątem $120^{\circ}$. Uchwyt w połowie długości ma przekrój czworoboczny i lekko zwęża się, a w dalszej części jest tordowany. Zakończenie ma formę owalnej płytki zdobionej plastycznym motywem. Długość zachowana przedmiotu wynosi $130 \mathrm{~mm}$, długość trzonka $93 \mathrm{~mm}$, a szerokość 5-16 mm. Analogiczny ze względu na zastosowany materiał, formę oraz zdobienie okaz pochodzi z Targu Siennego w Gdańsku ${ }^{37}$. Omówiona łyżka z Wałowej 40 pochodzi ze studni datowanej na XVIII w. Wydaje się jednak, że należy ją łączyć z XVI-XVII stuleciem.

Do piątego typu można zaliczyć jedną łyżkę (ryc. 13). Zachowana w całości, składa się z owalnego czerpaka oraz łukowato wygiętego trzonka. Od nasady do

36 Cornelis Mahu, Śniadanie Martwa Natura, lata 30. Xvil w. (Museum voor Schone Kunsten, Ghent), https://www.wga.hu/html_m/m/mahu/breakfas.html [26 IX 202I].

37 Obiekt był prezentowany na wystawie stanowiącej podsumowanie prac archeologicznych, nie został jednak ujęty w katalogu (autorka współtworzyła tę ekspozycję). 


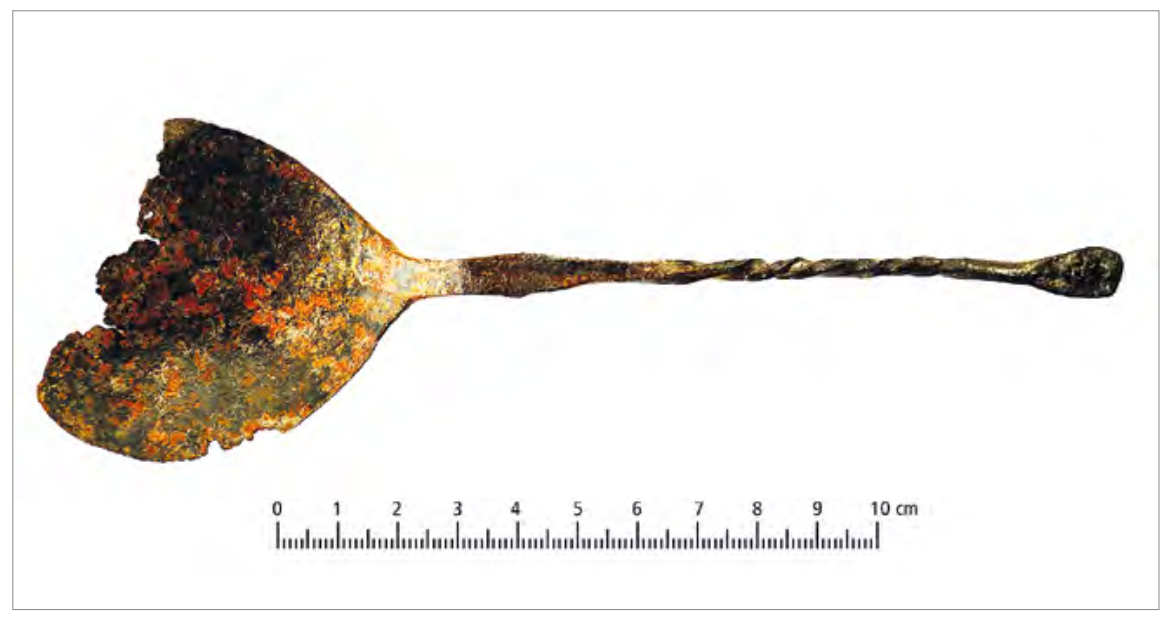

Ryc. 12. Łyżka stołowa żelazna, pokryta cyną typ IV (fot. M. Wołyńska).

połowy długości ma przekrój półkolisty, w dalszej części jest spłaszczona i rozszerzona wachlarzowato. Strona wierzchnia płaskiej części trzonka jest zdobiona biegnącym wzdłuż, delikatnym żeberkiem przechodzącym w wachlarzowaty wypustek. Długość całkowita łyżki to $207 \mathrm{~mm}$, natomiast trzonka I20 mm przy szerokości s-24 mm, a czerpaka $87 \mathrm{~mm}$ przy szerokości $42 \mathrm{~mm}$. W XVII i XVIII w. łyżki zmieniają kształt. Trzonek przybiera formę płaskiej listewki rozszerzającej się na końcu w uchwyt, ponieważ łyżka jest trzymana teraz trzema palcami od dołu, a nie jak dotąd od góry ${ }^{38}$. Na stole łyżki układane są wnętrzem czerpaka do góry (Bobrow 1998: 20-22). Upowszechnienie się sztućców pociągnęło za sobą dalszy rozwój form i zdobienia ${ }^{39}$. Prezentowany zabytek (ryc. 13) to łyżka z uchwytem hanowerskim ${ }^{40}$. Styl ten pojawił się w Anglii około i7ıo r. Nazwa związana była z popularnością formy w okresie panowania dwóch pierwszych przedstawicieli dynastii hanowerskiej, królów Jerzego I i Jerzego II (I714-1760). W Muzeum Wiktorii i Alberta w Londynie można wskazać liczne srebrne okazy tego rodzaju, w tym najbliższą analogię dla omawianego zabytku (ryc. 13), tj. wyrób warsztatu londyńskiego, datowany na lata $1732-1733^{41}$. Obydwa przedmioty mają

$38 \mathrm{~W}$ ten sposób chwytano egzemplarze typu I-4 prezentowane powyżej. Te wcześniejsze łyżki kładziono też inaczej na stole, czerpak skierowany był do krawędzi stołu (Bobrow 1998: 7).

39 https://www.wilanow-palac.pl/dekoracje_sztuccow.html [9 V 2019].

40 https://www.wilanow-palac.pl/dekoracje_sztuccow.html [9 V 2019].

41 Lyżka srebrna typu hanowerskiego, wytwórca nieznany, Londyn, lata 1732-1733 (Victoria \& Albert Museum, nr kat. 125-1903), http://collections.vam.ac.uk/item/O $271838 /$ spoon-unknown/ [9 V 2019]. 
specyficznie ukształtowany spód przejścia trzonka w czerpak, przypominający kroplę. Taka forma była charakterystyczna dla tyżek produkowanych po $1730 \mathrm{r}^{42}$ Przykład zbliżonego, cynowego artefaktu znany jest z muzeum w Birmingham (59'56-260) (Old Pewter... bd: I4 - trzecia łyżka od lewej, 20, 2I). Eyżka jest sygnowana znakiem x pod koroną, różą oraz trzema literami majuskułowymi (s P A) wskazującymi na właściciela. Nazwa wytwórcy nie jest czytelna. Przedmiot uznano za angielski i datowano na połowę XVIII w. (Old Pewter... bd: is). $\mathrm{Z}$ uwagi na sygnaturę wykonaną na łyżce ze stanowiska przy Wałowej 40 można przyjąć, że stanowiła ona import z Londynu. Obiekt o takiej proweniencji odkryto również w Amsterdamie, gdzie datowany jest na pierwszą połowę XVIII w. (Baart, Krook 1977: 32I - poz. 605). Zarówno on, jak i kolejne, określane na drugą połowę XVIII w. lub szerzej, na okres całego stulecia (Baart, Krook 1977: 32I - poz. 606, 607, 608), posiadają sygnatury potwierdzające pochodzenie z londyńskiego warsztatu. Natomiast zaledwie fragment analogicznego, cynowego trzonka pochodzi z Holandii, $\mathrm{z}$ twierdzy Bourtange. Zabytek jest datowany na okres od drugiej połowy XVIII po pierwszą ćwierć XIX w. (Calisch 1993: 552, ryc. 75). Omawiany typ łyżki był od pierwszej dekady XVIII w. aż do około 1770 r. rozpowszechniony w całej Europie ${ }^{43}$. Przedmioty o analogicznej formie prawdopodobnie wytwarzano w Amsterdamie (Baart, Krook 1977:311 - poz. 588, 312 - poz. 589, 590, 591). Były one znakowane na stronie spodniej herbem tego miasta. Również zabytki pozyskane w trakcie badań archeologicznych prowadzonych w Amsterdamie są datowane na drugą połowę XVIII w. lub szerzej na całe stulecie. Trzy zbliżone pod względem formy tyżki stwierdzono również we wraku statku General Carleton, który został zwodowany w 1777 r., a zatonął osiem lat później u południowych wybrzeży Bałtyku, w okolicy Dębek (powiat pucki). Jedna z nich była sygnowana na spodniej stronie trzonka, m.in. wyrytą literą X, pozostałe znaki nie były czytelne (Wrak statku... 2008: 4I-45, 67, tabela I, 386, 387). Czwarty z przedmiotów nie został zilustrowany, ale według opisu na spodniej stronie jego trzonka umieszczono inicjały ER oraz napis LONDON (Wrak statku... 2008: 386). Prezentowana łyżka pochodzi z wypełniska studni datowanego na XVIII w. Na podstawie wskazanych analogi oraz kontekstu pozyskania okaz można łączyć prawdopodobnie z drugą ćwiercią XVIII stulecia.

\section{Zdobienie}

W trakcie omówienia formy łyżek, wskazane zostały rozmaite sposoby plastycznego zdobienia trzonków wpływające na ich kształt. Typowo dekoracyjny charakter ma natomiast wykonany płaskim chwiejakiem (na osi trzonka) ornament ryty

42 http://collections.vam.ac.uk/item/O271838/spoon-unknown/ [9 V 2019]. 43 http://collections.vam.ac.uk/item/O271838/spoon-unknown/ [I IV 2019]. 
w formie linii tremolowanej (zygzakowatej) (ryc. II: 3). W tej samej technice zdobiony jest fragmentarycznie zachowany czerpak wspomnianej łyżki. Line tremolowane podkreślają krawędzie czerpaka oraz obwodzą umieszczony w jego górnej części gmerk. Wybór tego typu zdobienia był wynikiem właściwości fizycznych cyny. Miękki metal stanowi bowiem idealny materiał do stosowania techniki rycia (Tuchołka-Włodarska 1992: 8). Linia tremolowana o zróżnicowanych ząbkach umożliwiała stosunkowo proste wykonanie dekoracji na dużej powierzchni. Omówiona technika była popularna w XVI i XVII stuleciu i została wykorzystana na przykład do ozdobienia czerpaka łyżki z Muzeum Narodowego w Gdańsku, datowanej na przełom XVI i XVII w. (Tuchołka-Włodarska 1992: IO2 - poz. 75). W pozyskanym podczas wykopalisk materiale zastosowano również reliefowy, wypukły ornament. W jednym przypadku część zachowanego trzonka zdobi ornament geometryczny (ryc. II: 6), w kolejnym motyw prawdopodobnie w formie stylizowanej wici roślinnej (ryc. II: 7), jednak trudno to jednoznacznie stwierdzić z powodu słabego stanu zachowania. Przykłady łyżek z ornamentem reliefowym można wskazać w zbiorze zabytków cynowych Muzeum Narodowego w Gdańsku (Tuchołka-Włodarska 1992: 103 - poz. 76 i 77). Są to przedmioty o metryce XVII-wiecznej. W ten sposób jest też zdobiony trzonek łyżki z fosy miejskiej we Wrocławiu (Wiśniewski 1993: 339, ryc. 4:f). Wypukłą, plastyczną formę ma również ornament w postaci schematycznego, czteropłatkowego kwiatu umieszczonego na końcu trzonka żelaznej łyżki pokrytej pierwotnie cyną (ryc. I2).

\section{Znaki wytwórców}

Zorganizowanie cechu konwisarzy pociągnęło za sobą obowiązek znakowania wyrobów. Członkowie gildii przedmioty cynowe sygnowali wyciśniętą żelaznym stemplem puncą. Znak wskazywał na ilość ołowiu w stopie i stanowił gwarancję jakości produktu, szczególnie istotną w przypadku zastawy stołowej. Ołów mimo szkodliwości był istotną częścią procesu technologicznego, gdyż pozwalał na zmniejszenie kruchości cyny (Tuchołka-Włodarska 1978: 77, przypis I).

W omawianym zbiorze sygnatury stwierdzono na dziewięciu zabytkach, z czego siedem zlokalizowano w górnej części czerpaka (ryc. IO: I-5; II: 3, 5), a jedną

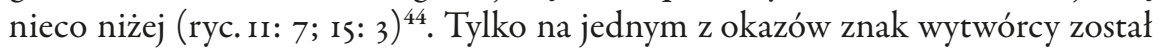
umieszczony na spodniej stronie trzonka (ryc. 13). Należy zwrócić uwagę, że sygnatury odciśnięte na zachowanych czerpakach wystąpiły na $88 \%$ tyżek cynowych. Pośród znaków wytwórców można wskazać pięć typów. Mimo różnic, często powtarzający się, wspólny element stanowi monogram producenta w postaci majuskuły. Pierwszy typ jest reprezentowany przez cztery egzemplarze (ryc. IO: I, 4;

44 Sygnatury mają wymiary od 2 x $4 \mathrm{~mm}$ po 7-8 x 9-I2 mm, przy czym dominują te większe. 
II: 3, 7; I5: I-4). Sygnatura ma postać gmerka umieszczonego w owalnym polu. W dwóch przypadkach jest to czwórka Merkurego, której towarzyszą występujące dwa razy: po jej bokach oraz na jej przedłużeniu litery M, K (ryc. IO: I, 4; I5: I, 2). W trzecim, źle zachowanym, czwórka Merkurego pojawia się razem z gmerkiem $\mathrm{w}$ formie lustrzanego odbicia cyfry I. Ten element przechodzi w widoczną poniżej majuskułę $\mathrm{M}($ ?) (ryc. I5: 3). Ostatni z gmerków jest słabo czytelny, ale zawiera również znak przypominający lustrzane odbicie cyfry i i kolejny nawiązujący kształtem do majuskuły P (ryc. II: 3; I5: 4). Do drugiego typu można zaliczyć dwa zabytki (ryc. I0: 3; II: 5; I5: 5, 6). Sygnatura składa się w tym przypadku z tarczy herbowej. W jej polu umieszczono prawdopodobnie litery M i B zwieńczone literą/krzyżem(?) (ryc. Io: 3; I5: 5) lub skrzyżowaną w formie x parę złożoną z krzyża i zbliżonego do niego elementu (ryc. II: 5; I5: 6). Trzeci typ reprezentuje jedna z łyżek (ryc. Io: 5; I5: 7), tu znak wytwórcy składa się z rozety (w typie róży Tudorów) zwieńczonej koroną otwartą ${ }^{45}$ i flankowanej majuskułami P i D. Rozetę cechuje charakterystyczny dla XVII w. rozmiar, wynoszący poniżej I cm oraz głęboki relief (Tuchołka-Włodarska i98ı: 76). Analogiczną sygnaturę posiada łyżka datowana na pierwszą ćwierć XVII w., pochodząca ze zbiorów Muzeum Narodowego w Gdańsku. Jest to wyrób z partackiego warsztatu Petera Dralanda, który prawo do produkowania łyżek otrzymał w I6ro r. (Tuchołka-Włodarska I981: 20, 8I, tab. I, nri, I04 - poz.78). Znakowanie wyrobów było stosowane nie tylko przez członków cechu, ale i przez partaczy, którzy sygnowali swój towar już w XVI w. (Tuchołka-Włodarska I98I: 78). Znaki konwisarskie wskazywały na gatunek surowca, z którego powstał wyrób, czyli miały wpływ na jego atrakcyjność dla nabywców. Stwierdzona na łyżce ze stanowiska przy Wałowej 40 róża z koroną, która w przypadku angielskiej cyny stanowiła znak najwyższej jakości, była stosowana w Gdańsku już w połowie XVI w. Najstarsza wzmianka o użyciu tej sygnatury przez partaczy ze Szkotów pochodzi z edyktu z I556 r., który zakazywał tej praktyki, a także sprzedaży wyrobów konwisarskich na jarmarkach. Z zachowanych źródeł gildii wynika, że cech w drugiej połowie XVII w. nakładał obowiązek oznakowania nią najlepszego stopu cyny (Tuchołka-Włodarska I981: 74, 77).

45 Należy podkreślić, że pięcioptatkowa rozeta z korona, zwana róża Tudorów, stosowana byta w Anglii bardzo rzadko jako określenie cechu lub mistrza, natomiast wedtug rozporzadzenia z roku I67I obowiazywata na angielskich przedmiotach przeznaczonych na eksport (Tuchołka-Włodarska I978: 85). Najwyższą jakość angielskiej cyny potwierdzano za pomocą koronowanego znaku róży do końca XVII w. (Hall, Gadd 200I: 3). Od ostatniej dekady tego stulecia była już stosowana do znakowania wyrobów angielskich produkowanych na rynek krajowy (Hall, Gadd 200I: 3). Róża Tudorów stanowiła sygnaturę najbardziej rozpowszechnioną na kontynencie (Tuchołka-Włodarska 1978: 85), na którym pojawiła się już na początku XVI stulecia. Jej użycie spotykało się z zakazami, z uwagi na znacznie niższą jakość kontynentalnych stopów cyny (Weinstein 20II: 19I). 


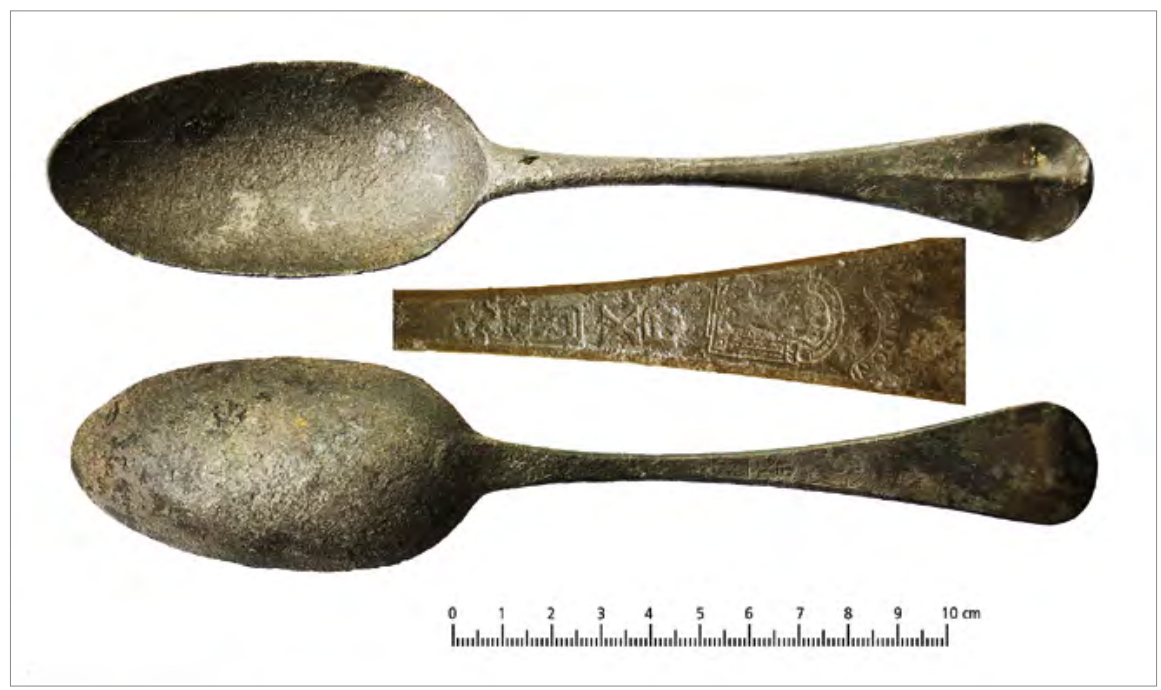

Ryc. 13. Łyżka stołowa cynowa typ v (typ hanowerski) (fot. M. Wołyńska).

Do czwartego typu przyporządkowano jeden zabytek (ryc. Io: 2; I5: 8). Znak wytwórcy ma w tym przypadku formę przypominającą poprzecznie wybitą cyfrę 8 . Jest to najmniejsza z sygnatur. Brak jak dotąd analogii dla tego znaku.

Piąty typ jest wyjątkowy z uwagi na lokalizację znaku wytwórcy (ryc. 13). Został on umieszczony na zewnętrznej stronie trzonka, w jego środkowej części. Sygnatura składa się z prostokątnego pola z majuskułami KNES(?) oraz zlokalizowanej powyżej, poprzecznie w stosunku do osi trzonka, litery $\mathrm{x}$ pod koroną. Nad nią umieszczono w portalu(?) lub pod arkadą ${ }^{46}$ anioła, a powyżej banderolę z napisem LONDON (ryc. I5: 9). Koronowany „X” stanowił kolejny - po sygnaturze róży - znak jakości używany na Wyspach Brytyjskich. Symbol został opracowany pod koniec XVII w. w Londynie, dla potwierdzenia wysokiej jakości stopu złożonego z cyny, antymonu i miedzi. Z czasem nastąpiła dewaluacja tej sygnatury ${ }^{47}$. Jej obecność na XIX-wiecznych wyrobach nie miała już związku z jakością przedmiotu (Cotterell 1969: 49; Hall, Gadd 200ı: 3). Natomiast znak anioła, według badaczy brytyjskich (Hall, Gadd 200I: 3), pojawił się jako oznaczenie cyny najwyższej próby w drugiej połowie XVIII w. W ich opinii nie był on jednak używany w handlu lokalnym na Wyspach Brytyjskich. Zbliżona sygnatura była stosowana

46 Odbicie niestaranne, brak fragmentu lewej strony.

47 Początkowo stosowanie koronowanej róży lub znaku x było kontrolowane, a za niewłaściwe wykorzystanie groziły grzywny i inne surowe kary (Cotterell 1969: 49). 
przez kilku wytwórców londyńskich działających w latach: 1673/1674 (Cotterell 1969: 306 - poz. 4305), 1719 (Cotterell 1969: 246 - poz. 2674), 1707-1766(?) (Cotterell 1969: 245 - poz. 2662), 1727-1750 (Cotterell 1969:245 - poz. 2663) czy 1779-1804 (Cotterell 1969: 152 - poz. 174). Analogie dla tej sygnatury mogą stanowić znaki ze wspomnianych już łyżek odkrytych w Amsterdamie (Baart, Krook 1977: 320, il. il 4:b-d), o identycznej lokalizacji i rozplanowaniu symboli. Sygnatura ich składa się z podłużnego pola, znaku $\mathrm{x}$ zwieńczonego koroną otwartą lub zamkniętą (Baart, Krook 1977: 320, il. I1 4:b-d) oraz umieszczonej powyżej tarczy herbowej (Baart, Krook 1977: 320, il. II 4:d). W przeciwieństwie do prezentowanego egzemplarza, gdzie być może mamy do czynienia z nazwą wytwórcy(?) (ryc. I5: 9), w przytoczonych zabytkach w polu znajduje się majuskułowy napis LONDON. Tarcza herbowa występuje tylko w sygnaturze na jednej łyżce i w przeciwieństwie do tej ze stanowiska przy Wałowej 40, umieszczono w niej siedzącego psa (Baart, Krook 1977: 320, il. II 4:d). Artefakty datowane są na pierwszą połowę lub cały XVIII w. (Baart, Krook 1977: 321 - poz. 605-607). Dla motywu anioła można wskazać jeszcze jedną, nieco odmienną analogię. Z Amsterdamu pochodzi łyżka ze znakami w postaci: majuskuł LD, przyklękającego na jedno kolano anioła z trąbką i stojącego lwa. Zabytek datowany jest na drugą połowę XVIII w. (Baart, Krook 1977: 320, il. II 4:e, 32I).

\section{Łyżka kuchenna jako przykład sprzętów używanych do przygotowania posiłków}

Podczas badań na stanowisku przy Wałowej 40 pozyskano również żelazną, kutą łyżkę kuchenną (ryc. I4). Przedmiot składa się z kolistego czerpaka przechodzącego w rozszerzającą się ku wylotowi, owalną w przekroju, sklepaną od spodu tuleję do osadzenia trzonka. Długość łyżki wynosi $130 \mathrm{~mm}$, czerpaka $37 \mathrm{~mm}$, przy zachowanej szerokości $40 \mathrm{~mm}$ i głębokości około $7 \mathrm{~mm}$. Tuleja przy długości $93 \mathrm{~mm}$, ma szerokość $5-16 \mathrm{~mm}$. Dwie żelazne łyżki kuchenne zostały odkryte również podczas badań w obrębie jatek mięsnych w Gdańsku (Trawicka 2018: 344, 370, ryc. I3: kat. 2641, 2642). Szczególnie jedna z nich, zaopatrzona w tuleję (Trawicka 2018: 370, ryc. 13:264I), może stanowić analogię dla omawianego zabytku. Przedmiot ten jest jednak niemal dwa razy większy. Jego długość wynosi około $220 \mathrm{~mm}$, a szerokość czerpaka ponad $80 \mathrm{~mm}$. Łyżka należy do zbioru dość spójnego chronologicznie, obejmującego głównie okres XIV-XV stulecia (Trawicka 20I8: 335). Analogiczny, nieco większy żelazny okaz (dt. $155 \mathrm{~mm}$, czerpak o średnicy $60 \mathrm{~mm}$ i głębokości około I4 mm), określony jako „chochelka”, pozyskano z okolic puckiego ratusza (Miścicki 2017: 206, 2II, ryc. VIII.8:19). Należy zaznaczyć, że ta kategoria artefaktów sprawia duże problemy chronologiczne z uwagi na uniwersalną formę. Zbliżoną łyżkę możemy zobaczyć również na karcie przedstawiającej 


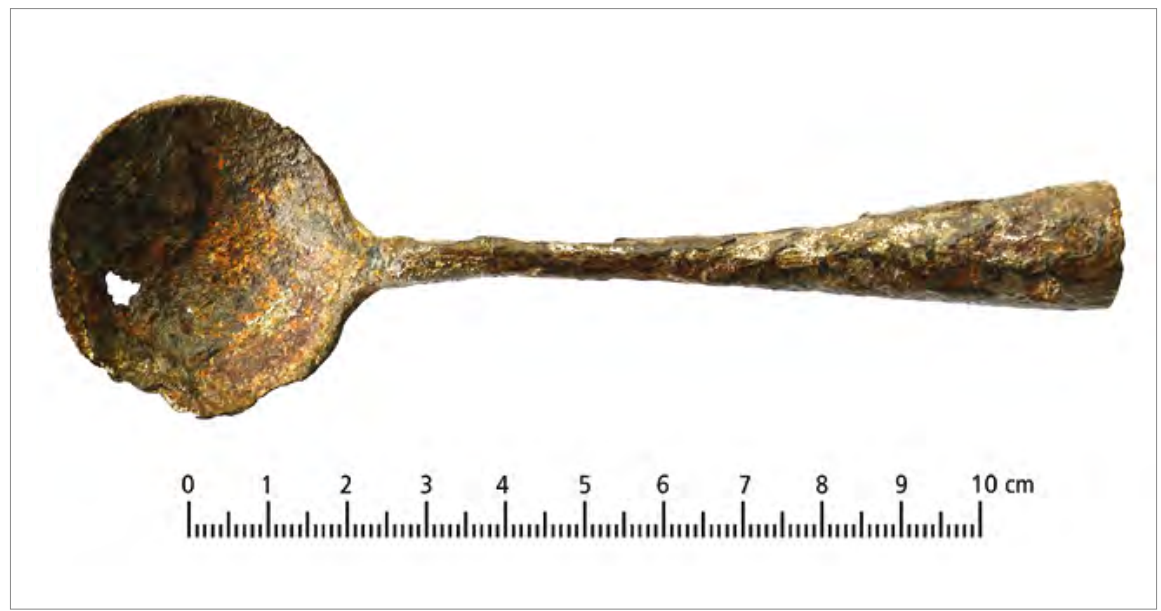

Ryc. 14. Łyżka kuchenna żelazna (fot. M. Wołyńska).

kucharza z Domowej Księgi fundacji Konrada Mendela z 1527 r. ${ }^{48}$ Zabytek ze stanowiska przy Wałowej 40 pozyskano z zasypiska fosy datowanego na drugą połowę XVII w., co stanowi terminus ante quem dla użytkowania przedmiotu. Natomiast kwestia dolnej cezury jest trudna do ustalenia.

\section{Analiza kufla cynowego}

W efekcie prac archeologicznych na stanowisku przy ulicy Wałowej 40 pozyskano kufel cynowy (ryc. I6). Przedmiot jest zachowany w całości, choć nieco zdeformowany i uszkodzony przy dolnej części ucha. Naczynie o kształcie konicznym rozszerza się przy podstawie, a od góry zamknięte jest wypukłą pokrywą z umieszczonym na środku profilowanym zwieńczeniem w formie gałki. Przy zawiasie znajduje się uchwyt z wygiętego, rozszerzającego się płaskownika ozdobiony reliefową maską(?). Ucho jest płaskie, pierwotnie esowato wygięte, o zakończeniu analogicznym jak uchwyt przy zawiasie. Tuż przy górnej nasadzie ucha, na stronie wierzchniej, naniesiona została sygnatura (ryc. I5: IO). Składa się ona z dwóch tarcz. W lewej jest znak wytwórcy złożony z majuskuł I(?)P, przeciętych w dolej części poprzeczną belką. W prawej umieszczono herb Gdańska(?) lub Elbląga(?) w postaci dwóch krzyży. Kufel ma wysokość $190 \mathrm{~mm}$. Średnica pokrywy wynosi $76 \mathrm{~mm}$, a dna $95 \mathrm{~mm}$. Trudno wskazać bezpośrednie analogie dla tego naczynia.

48 Kucharz - 1527 r. (Hausbuch der Mendelschen... Bd. I: Amb. $317.2^{\circ}$ Folio 142 recto), https://www.nuernberger-hausbuecher.de/75-Amb-2-317-I 42-r [26 IX 202I]. 


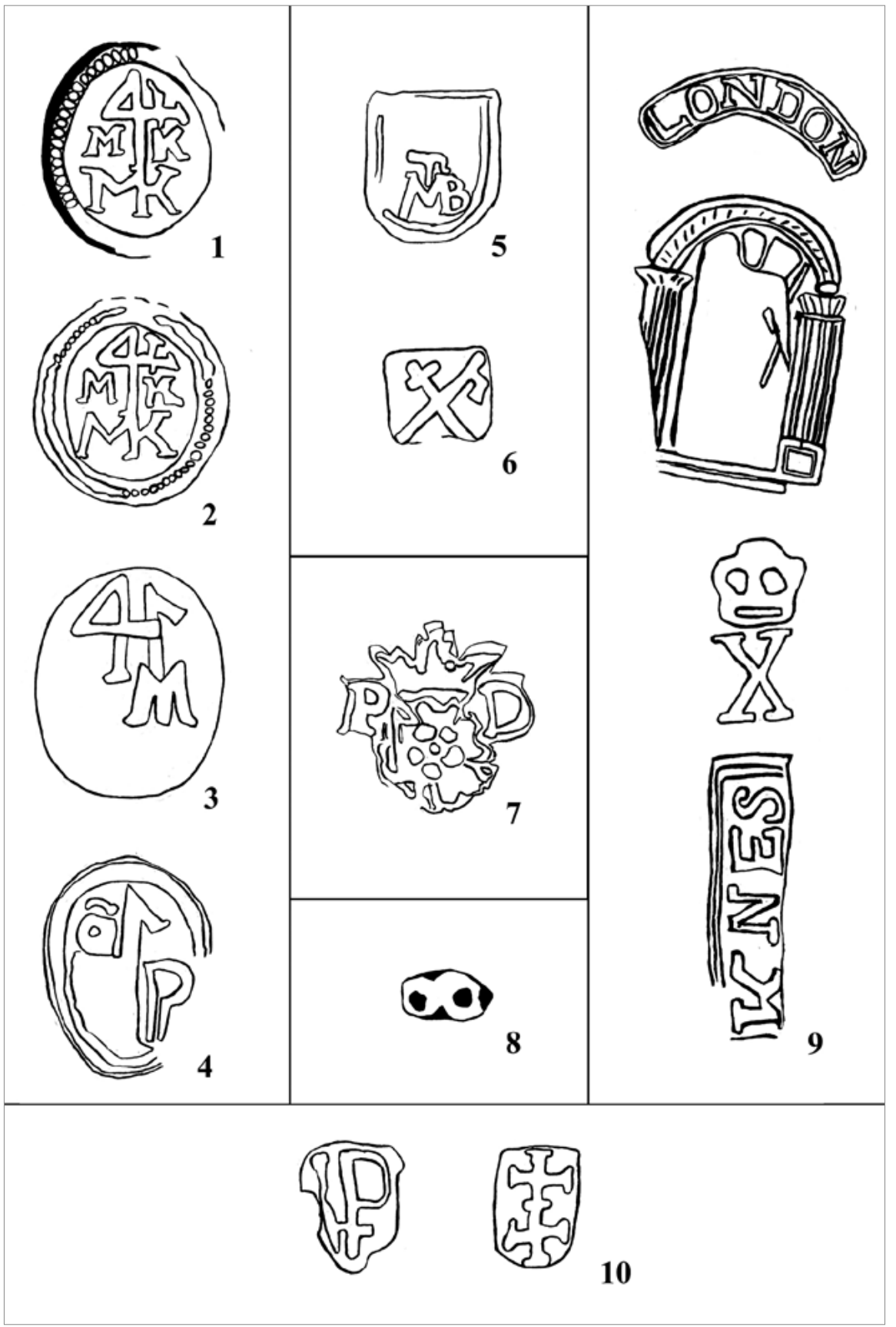

Ryc. 15. Znaki wytwórców wybite na łyżkach (I-9) oraz na kuflu (Io) (rys. M. Wołyńska). 


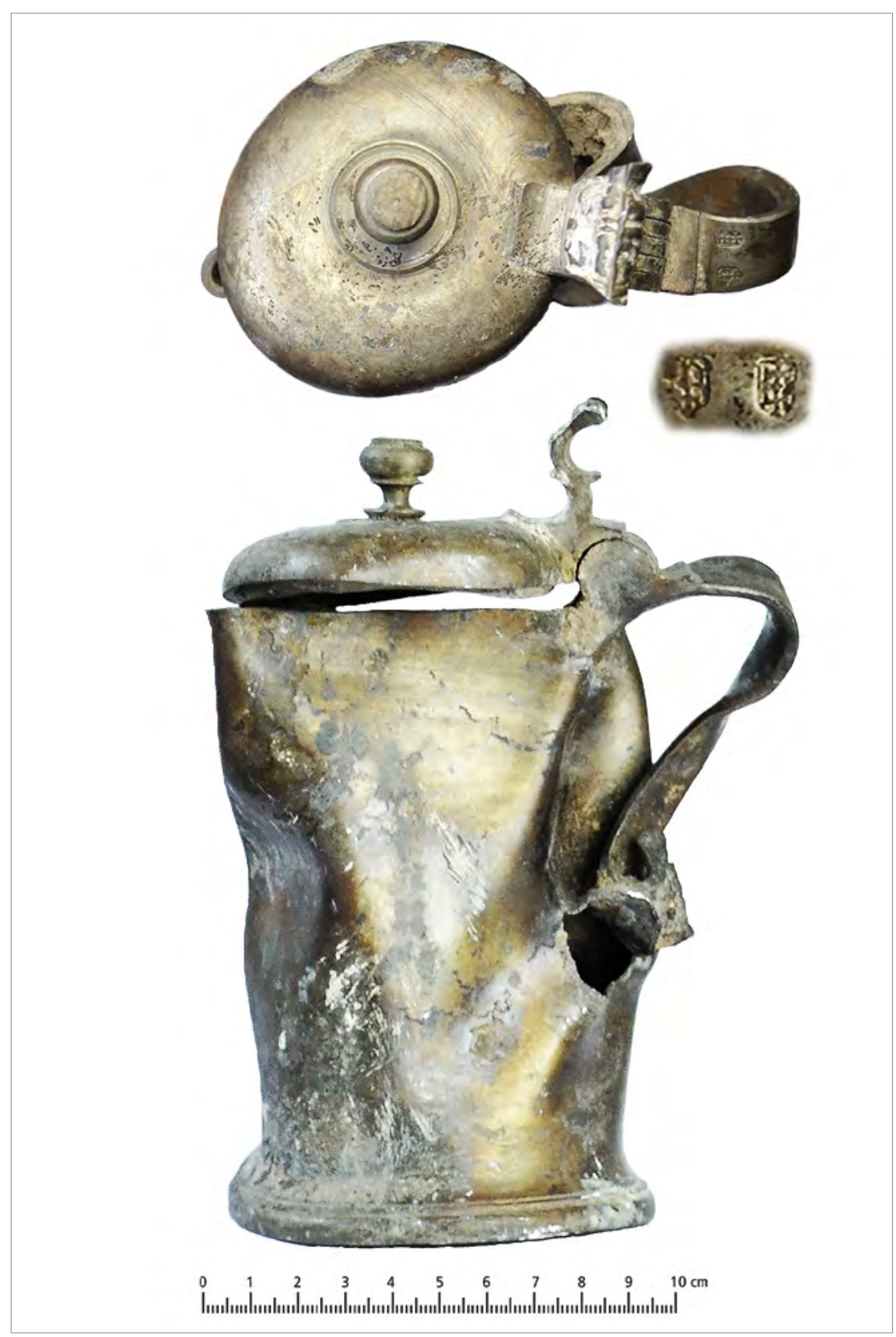

Ryc. 16. Kufel cynowy (fot. M. Wołyńska). 


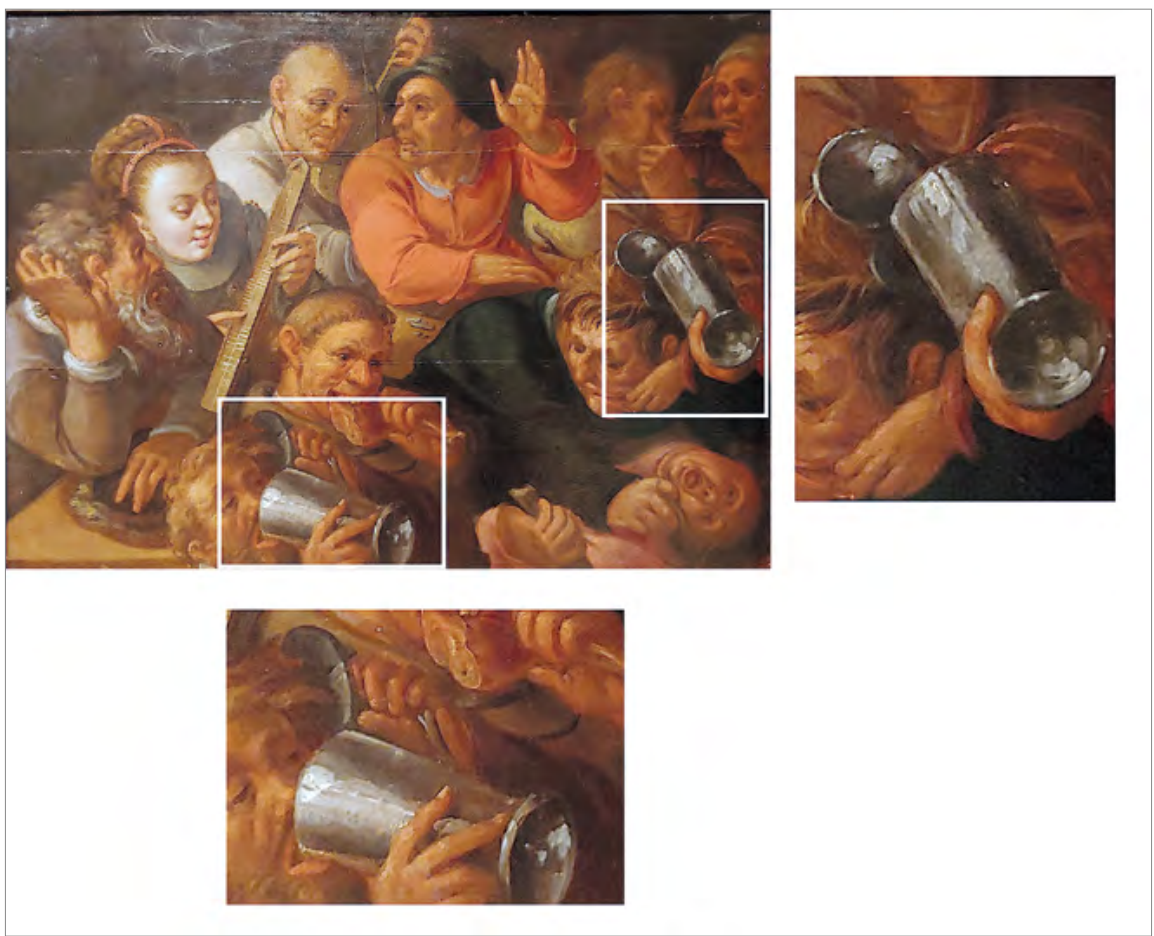

Ryc. 17. Anton Möller, Alegorie pięciu zmystów (Scena w gospodzie), przed I6II r. (Muzeum Narodowe w Gdańsku) (fot. M. Waligóra).

Zbliżoną formę ma datowana na około 1606 r. konew elbląskiego cechu szyprów (Niemcewicz-Ledwoń 1988: 31, 32, il.27), jest to jednak naczynie dwa razy większe. Wyobrażenie podobnego kufla (bardziej rozszerzonego przy podstawie) widoczne jest na karcie z przedstawieniem szewca, pochodzącej z Domowej Księgi fundacji Konrada Mendela ${ }^{49}$. Zbliżone naczynia można zobaczyć też na pochodzących z pierwszej dekady XVII w. obrazach gdańskiego malarza Antona Möllera $^{50}$ (ryc. 17). Nie udało się połączyć pojemnika z którymś z gdańskich warsztatów. Na podstawie sygnatury można jednak określić jakość stopu, który posłużył do produkcji kufla. Zatwierdzenie prób cyny ${ }^{51}$ oraz przyjęcie sygnowania wyrobów herbem miasta i znakiem konwisarza zostało przyjęte po raz pierwszy w państwie

49 Warsztat szewca - I555 r. (Hausbuch der Mendelschen... Bd. II: Amb. 317 b. $2^{\circ}$ Folio 6 verso), https://www.nuernberger-hausbuecher.de/75-Amb-2-317b-6-v [26 IX 202I].

50 Anton Möller, Orkiestra pijacka, około I6ı r. (Polska Akademia Nauk Biblioteka Kórnicka), https://www.gedanopedia.pl/gdansk/?title=M\%C3\%96LLER_ANTON [26 IX 202I].

$51 \mathrm{O}$ tej kwestii, ale w kontekście wyrobów ze Śląska, wspomina również Borys Paszkiewicz i Krzysztof Wachowski (2018: 505). 
krzyżackim na zjeździe przedstawicieli stanów i miast pruskich w I432 r. w Elblągu (Tuchołka-Włodarska 1978: 78). Połączenie herbu miasta i znaku konwisarza było wzorowane na niemieckich przepisach cechowych. Dla wyrobów z miast Prus Królewskich i Prus Książęcych, datowanych na okres nowożytny, oznaczało to drugi gatunek stopu cyny (Tuchołka-W łodarska 1978: 8I). Tak zwana „cyna pospolita” zawierała dwie części cyny i jedną ołowiu (Tuchołka-Włodarska 1978: 84).

Kufel pozyskano z zasypiska fosy datowanego na drugą połowę XVII w. i wydaje się, że czas jego powstania należy łączyć z tym stuleciem.

Gdański rynek wyrobów cynowych w świetle konkurencji
pomiędzy cechem konwisarzy a podmiejskimi partaczami

Pośród rzemieślników parających się odlewnictwem najliczniejszą grupę stanowili konwisarze ${ }^{52}$.Specyfika ich zawodu polegała na szerokim asortymencie produktów, który obejmował zarówno przedmioty codziennego użytku, spotykane w każdym domu, jak i wyroby o walorach artystycznych, kierowane do bogatego mieszczaństwa oraz organizacji rzemieślniczych i kupieckich (Bogucka 1962: 108).

Wyroby cynowe były cenne ze względu na zastosowany materiał. Cyna to łatwo topliwy metal, który płynną postać osiąga w temperaturze 230 stopni. Odlewana była głównie z domieszką ołowiu i miedzi w formach wykonanych z gliny zmieszanej z włosiem cielęcym. Miękki, ale i kruchy metal był wykorzystywany do tworzenia masywnych form o srebrzystobiałych, dużych powierzchniach (Tuchołka-Włodarska 1992: 8). Cech konwisarzy kontrolował nie tylko wytwarzanie przedmiotów, ale miał również monopol na skup złomu cynowego (Tuchołka-Włodarska 1992: 77). Metal stanowiący różnoprocentowy stop cyny zyskiwał na wartości po kolejnym przetopieniu. Powtarzanie tego procesu umożliwiało oczyszczenie metalu, zwiększenie jego twardości, dźwięczności i połysku, a przez to i podnoszenie jakości wyrobów (Tuchołka-Włodarska 1992: 76). W świetle tych informacji zastanawiające jest znalezisko omówionego powyżej kufla cynowego. Z łatwością mógł bowiem zostać wykorzystany do wyrobu nowego naczynia czy łyżki. Przedmioty tego typu są słabo reprezentowane w materiale archeologicznym. Z terenu Gdańska znane są dwie XVI-wieczne cynowe konwie. Pierwsza została odkryta podczas prac przy ulicy Świętego Ducha (Gdańsk w Europie... 20II: 25, ryc. II), kolejna, bardzo zdeformowana konew typu hanzeatyckiego wystąpiła na stanowisku przy ulicy Jana z Kolna II (Leśniewska 20I4: 74, 8I, 85). W tej kategorii mieści się również datowana na okres XV-XVI w. idealnie zachowana

52 Warsztat konwisarza - I 428 r. (Hausbuch der Mendelschen... Bd. I: Amb. $317.2^{\circ}$ Folio 49 recto), https://www.nuernberger-hausbuecher.de/75-Amb-2-317-49-r [26 IX 2021]. 
cynowa solniczka, pozyskana podczas badań na Targu Siennym (Targ Sienny... 2016: 107 - poz. 182).

W kontekście łyżki (ryc. Io: 5) łączonej z warsztatem Petera Dralanda należy szerzej omówić kwestie cechu konwisarzy i jego konkurencji. Pierwszy z problemów stanowili rzemieślnicy niezrzeszeni w gildii ${ }^{53}$ (Tuchołka-Włodarska 1981: 65). Część partaczy zajmujących się konwisarstwem wywodziła się z gdańskich czeladników. Wysoki koszt uzyskania tytułu mistrza cechowego i problemy piętrzone przez cech stanowity dla tej grupy nieprzekraczalną barierę. Wytwórcy ci trafiali do osad rzemieślniczo-handlowych lokalizowanych poza murami miasta. Konwisarze osiedlali się w Szkotach, Chmielnikach i na Zaroślaku (Tuchołka-Włodarska 1981: 67). Olbrzymi rozrost gdańskiego rynku, który nastąpił po powrocie miasta do Korony, sprawil, że cechy nie były w stanie zaspokoić jego potrzeb (Tuchołka-Włodarska 1981: 66). Ta nowa sytuacja gospodarcza dawała szansę na awans społeczny. Bywało, że produkcja partaczy była legalizowana z uwagi na duże zapotrzebowanie na niewielkie przedmioty. Na tej zasadzie do gildii trafił wspomniany już Peter Draland z Zaroślaka, znany jako wytwórca łyżek, które sprzedawał pod Dworem Artusa (Tuchołka-Włodarska 1981: 71).

Drugim niekorzystnym czynnikiem dla rzemieślników zrzeszonych w cechu konwisarzy był handel naczyniami cynowymi przemycanymi z Anglii (Tuchołka-Włodarska 1981: 65). Wyroby te cieszyły się bardzo dużym zainteresowaniem $\mathrm{z}$ uwagi na zastosowanie stopu cyny pozbawionego szkodliwego ołowiu. Informacje o tym procederze znane są z XVII w., jednak takie praktyki miały zapewne miejsce już wcześniej. Na taką możliwość wskazuje obecność konwisarskiego znaku róży z koroną w XVI-wiecznym Gdańsku (Tuchołka-Włodarska 198I: 78). Pozytywnym aspektem tej konkurencji było stałe stosowanie dobrej jakości cyny przez gdańskich konwisarzy (Tuchołka-Włodarska 1981: 80).

\section{Wnioski}

Omawiane artefakty stanowią nowożytny zbiór wytworzonych z metalu przedmiotów kuchennych i stołowych. Zabytki zostały pozyskane głównie ze studni (25 egz.), datowanych na XVII (2 egz.) oraz XVIII w. (23 egz.). Pozostałe obiekty wystąpiły $\mathrm{w}$ warstwie niwelacyjnej średniowiecznego wału (2 egz.) wiązanej z okresem od drugiej połowy XVI po połowę XVII w., bądź w obrębie łączonego z drugą połową XVII stulecia zasypiska średniowiecznej fosy (4 egz.). Większość zabytków (19 egz.) z prezentowanego zbioru została wydatowana na XVII stulecie. Zaledwie pięć artefaktów zinterpretowano jako XVI-wieczne. Ramy chronologiczne dla kolejnych

53 Wyroby partaczy były też atrakcyjne dzięki niższej cenie (Tuchołka-Włodarska 1992: 77). 
pięciu określono na XVI-XVII w., z zawężeniem datowania dla pojedynczych egzemplarzy od schyłku XVI po pierwszą połowę XVII w. (I egz.) lub do pierwszej ćwierci XVII w. (I egz.). Dolną granicę chronologiczną całego zbioru wyznaczył wiek jednego z noży (ryc. 4: 4) wskazany na XV-XVI stulecie. Górną cezurę stanowi natomiast XVIII-wieczna metryka łyżki typu hanowerskiego (ryc. 13).

Opracowanie metalowych przedmiotów związanych z przygotowaniem i spożywaniem posiłków ze stanowiska przy ulicy Wałowej 40 stanowi próbę wypełnienia luki w wiedzy na temat tej kategorii gdańskich zabytków. Można tylko zastanawiać się, czy to być może codzienny, przyziemny charakter omówionych artefaktów wpłynął na znikome zainteresowanie tym aspektem życia. Konfrontacja sumy opracowań z liczbą pozyskanych podczas gdańskich prac wykopaliskowych przedmiotów wskazuje na konieczność dalszych badań. Pozwolą one w konsekwencji na wyciągnięcie bardziej prawidłowych wniosków opartych na większym materiale porównawczym.

\section{Bibliografia}

\section{Źródła}

APG - Archiwum Państwowe w Gdańsku

\section{Opracowania}

Amme J.(2002), Historische Bestecke. Formenwandel von der Altsteinzeit bis zur Moderne, Arnoldsche, Stuttgart.

Amme J. (2007), Historische Bestecke II. Supplement zu AMME 2002, Arnoldsche, Stuttgart.

Amme J. (2012), Historische Bestecke III. Von der Frühzeit bis in die Zeit um I60o, Arnoldsche, Stuttgart.

Baart J., Krook W.i in. (1977), Opgravingen in Amsterdam, Fibula-Van Dishoeck, Amsterdam. Bobrow R. (1998), Dawne sztućce, Pagina, Warszawa.

Bogucka M.(1962), Gdańsk jako ośrodek produkcyjny w XIV-XVII w., Państwowe Wydawnictwo Naukowe, Warszawa.

Burrows J., Niemann M. (2000), Rostocker Studentenleben in der ersten Hälfte des I6. Jahrhunderts. Archäologische und historische Belege, „Zeitschrift für Archäologie des Mittelalters", $27 / 28$, s. 163-184.

Calisch A. (1993), Bestek, [w:] J.J. Lenting, H.van Gangelen, H.van Westing (red.), Schans op de Grens. Bourtanger bodemvondsten 1580-1850, SPA Uitgevers, Sellingen, s. 537-556.

Cotterel H.H. (1969), Old Pewter its Makers and Marks, in England, Scotland and Ireland. An Account of the Old Pewterer \& his Craft, Rutland, Vermont.

Cowgill J., de Neergaard M., Griffiths N. (1987), Knives and Scabbards. Medieval Finds from Excavations in London, vol. I, Her Majesty's Stationery Office, London.

Folke G., Holtmann W. (1993), Untersuchung zu mittelalterlichen und frühneuzeitlichen Messern, Göttingen (phD dissertation). 
Gdańsk w Europie Europa $w$ Gdańsku. Kontakty handlowe i kulturowe Gdańska w świetle wykopalisk archeologicznych. Katalog wystawy (20II), Muzeum Archeologiczne w Gdańsku, Gdańsk.

Gomoliszek A. (2016), Noże z wykopalisk przy ulicy Chmielnej 73-74 w Gdańsku, „Dantiscum", I, s. 377-454.

Grupa M. (2007), Przyczynek do historii późnośredniowiecznych sztućców, „Archaeologia Historica Polona", 17, s. 433-437.

Haedecke H.-U. (1981), Bestecke. (Deutsches Klingenmuseum Solingen), Rheinland-Verl., Köln-Bonn.

Hall D.W., Gadd J. (200I), The Pewter Collection. Identification and Listing by Members of the Pewter Society, Dublin.

Hausbuch der Landauerschen Zwölfbrüderstiftung, Bd. I, ISII-I706, Nürnberg.

Hausbuch der Mendelschen Zwölfbrüderstiftung, Bd. I, I426-I549, Nürnberg.

Hausbuch der Mendelschen Zwölfbrüderstiftung, Bd. II, I550-I79I, Nürnberg.

Historia Gdańska, t. I (1978), E. Cieślak (red.), Wydawnictwo Morskie, Gdańsk.

Historia Gdańska, t. II (1982), E. Cieślak (red.), Wydawnictwo Morskie, Gdańsk.

Historia kultury materialnej Polski w zarysie, t. III, Od XVI do potowy XVII w. (1978),

A. Keckowa, D. Molenda (red.), Ossolineum, Wrocław-Warszawa-Kraków-Gdańsk.

Hoeniger C. (2006), The Illuminated Tacuinum sanitatis Manuscripts from Northern Italy ca. 1380-1400. Sources, Patrons and Creation of a New Pictorial Genre, „Avista Studies in the History of Medieval Technology, Science and Art", 5, s. 51-82.

Ignasiak M. (2020), Próba rekonstrukcji zagospodarowania terenu Lastadii w czasach budowy statków wodnych woparciu o analizę stratygrafii stanowiska, [w:] B. Kościński (red.), Lastadia - najstarsza stocznia Gdańska w świetle badań archeologicznych, $\mathrm{Mu}-$ zeum Archeologiczne w Gdańsku, Gdańsk (Archeologia Gdańska, 7), s. 87-ı12.

Jagiełło S. (2017), Opracowanie historyczne działki przy ulicy Wałowej 40 w Gdańsku, Warszawa (maszynopis).

Jędrzejczak A. (2004), Późnośredniowieczne i nowożytne noże z Wyspy Spichrzów w Gdańsku, Toruń (maszynopis w bibliotece UMK).

Jędrzejczak-Skutnik A. (2020), Noże, [w:] B. Kościński (red.), Lastadia-najstarsza stocznia Gdańska w świetle badań archeologicznych, Muzeum Archeologiczne w Gdańsku, Gdańsk (Archeologia Gdańska, 7), s. 40I-424.

Kasprzak M.(2013), Noże ze stanowiska w potudniowo-zachodniej części kwartatu ulic: Dtugie Ogrody, Szafarnia, Angielska Grobla i Św. Barbary w Gdańsku, [w:] H. Panera (red.), Archeologia Gdańska, t. v, Muzeum Archeologiczne w Gdańsku, Gdańsk, s.309-336.

Konczewska M., Konczewski P. (2004), Zabytki metalowe z fosy miejskiej we Wroctawiu, „Wratislavia Antiqua”, 6, s. 89-205.

Konczewska M., Wachowski K.i in. (2010), Kultura materialna publicznej przestrzeni miasta w świetle zabytków ruchomych, „Wratislavia Antiqua”, II, s. 179-406.

Kriegseisen J. (2015), Podrożny komplet sztúców wykonany przez Johanna Bartolomowicza - ztotnika z Lidzbarka Warmińskiego, „Kwartalnik Historii Kultury Materialnej”, 63.I, s.93-104.

Krzywdziński R. (2013), Analiza przestrzenno-funkcjonalna archeologicznych reliktów zagospodarowania dziatek mieszczańskich z potudniowo-zachodniej części kwar- 
tatu ulic: Dtugie Ogrody, Szafarnia, Angielska Grobla i Św. Barbary w Gdańsku, [w: H. Panera (red.), Archeologia Gdańska, t. v, Muzeum Archeologiczne w Gdańsku, Gdańsk, s. 23-132.

Krzywdziński R. (2016), Analiza przestrzenno-funkcjonalna archeologicznych reliktów zagospodarowania potudniowej czéści Wyspy Spichrzów przy ulicy Chmielnej 73-74 $w$ Gdańsku, „Dantiscum”, I, s. 7-76.

Krzywdziński R. (2018), Jatki rzeźnicze Gtównego Miasta w Gdańsku w świetle źródet archeologicznych, [w:] A. Pudło, W. Ossowski, E. Trawicka (red.), Jatki mięsne w Gdańsku od XIV do XX wieku, Muzeum Historyczne Miasta Gdańska; Muzeum Archeologiczne, Gdańsk, s. 13-234.

Leśniewska D. (20I4), Analiza zabytków metalowych, [w:] J. Prager, A. Longa (red.), Opracowanie wyników ratowniczych badań archeologicznych na stanowisku ul. Jana z Kolna ir w Gdańsku, s. 66-86 (maszynopis złożony w Muzeum Archeologicznym w Gdańsku).

Mackiewicz M., Marcinkiewicz K., Piekalski J.(2014), Plac Nowy Targ we Wroctawiu w'sietle badań wykopaliskowych w latach 2010-20I2, „Archaeologia Historica Polona”, 22, s. 167-184, https://doi.org/10.12775/AHP.20I4.008

Marquardt K. (1997), Europäisches Essbesteck aus acht Jahrhunderten, Arnoldsche, Stuttgart.

Michalik P. (2007), Późnośredniowieczne i wczesnonowożytne noże z zamku w Pucku, Instytut Archeologii Uniwersytetu Warszawskiego, Warszawa (Światowit. Supplement Series P: Prehistory and Midle Ages, I5).

Miścicki M.(2017), Wyroby i produkcja przedmiotów metalowych w późnośredniowiecznym Pucku, [w:] M. Starski (red.), Puck. Kultura materialna matego miasta w późnym średniowieczu, Instytut Archeologii Uniwersytetu Warszawskiego, Warszawa, s. $193-238$.

Niemcewicz-Ledwoń B. (1988), Ztotnictwo i Konwisarstwo Elblaskie od XVII do XIX wieku, Muzeum, Elbląg.

Old Pewter at the Birmingham Museum, http://www.pewterbank.com/__-_Old_Pewter_ Spoons_pages_I-231_at_Birmingham_Museum.pdf [10 V 2019].

Omilanowska M.(2010), Defortyfikacja Gdańska na tle przeksztatceń miast niemieckich w XIX wieku, „Biuletyn Historii Sztuki”, 72, s. 293-334.

Paszkiewicz B., Wachowski K. (2018), Handel i wymiana. Nowa postać handlu (XIII-XV wiek). Przyktad Wroctawia, "Wratislavia Antiqua”, 23, s. 379-399.

Schans op de Grens. Bourtanger bodemvondsten 1580-1850 (1993), J.J. Lenting, H. van Gangelen, H.van Westing (red.), sPA Uitgevers, Sellingen.

Sil B., Burdziej M.(20I5), Stargard, ul. Marii Sktodowskiej-Curie, Gdańska i Światopetka, obszar dawnej kaplicy i cmentarza św. Jakuba, stan. IIa (AZP 32-Io/I67), „Stargardia”, 9 (2014), s.394-398.

Sprawozdanie z badań archeologicznych przy ulicy Wałowej 40 w Gdańsku (2017), A. Longa (red.) (maszynopis złożony w wUOZ w Gdańsku).

Szajt J. (2018), Dom i jego wyposażenie. Między kuchnią a stotem. Kultura stotu, „Wratislavia Antiqua", 23, s.379-399.

Targ Sienny w Gdańsku. Przedmieście europejskiej metropolii w świetle wykopalisk archeologicznych. Katalog wystawy prezentowanej w Ratuszu Gtównego Miasta w Gdańsku 
w okresie od I czerwca do 25 września 2016 roku (2016), R. Krzywdziński (red.), Muzeum Historyczne Miasta Gdańska, Gdańsk.

Trawicka E. (2010), Zabytki metalowe z Wyspy Spichrzów w Gdańsku (badania z 2004 roku), [w:] H. Paner (red.), Archeologia Gdańska, t. Iv, Muzeum Archeologiczne w Gdańsku, Gdańsk, s. 93-150.

Trawicka E.(2018), Zabytki metalowe, [w:] A. Pudło, W. Ossowski, E. Trawicka (red.), Jatki mięsne w Gdańsku od XIV do XX wieku, Muzeum Historyczne Miasta Gdańska; Muzeum Archeologiczne, Gdańsk, s. 335-388.

Trawicka E. (2020a), Katalog, [w:] B. Ceynowa (red.), Kawa czy herbata? Archeologiczne świadectwa konsumpcji napojów w dawnym Gdańsku, Muzeum Archeologiczne w Gdańsku, Gdańsk, s. 172.

Trawicka E. (2020b), Przygotowanie i spożywanie positków. Metalowe sprzęty kuchenne, [w:] B. Kościński (red.), Lastadia - najstarsza stocznia Gdańska w świetle badań archeologicznych, Muzeum Archeologiczne w Gdańsku, Gdańsk (Archeologia Gdańska, 7), s.329-332, 347 .

Tuchołka-Włodarska B. (1978), Znaki gdańskich konwisarzy, „Gdańskie Studia Muzealne”, 2, s. 77-98.

Tuchołka-Włodarska B.(198I), Konwisarstwo pozacechowe oraz import angielskich naczyń cynowych w Gdańsku w okresie od XVI do XVIII wieku, „Gdańskie Studia Muzealne”, 3, s. 65-82.

Tuchołka-Włodarska B. (1992), Cyna od XV do XIX wieku. Katalog statej wystawy ze zbiorów Muzeum Narodowego w Gdańsku, Muzeum Narodowe w Gdańsku, Gdańsk.

Weinstein R. (201I), The Archaeology of Pewter Vessels in England I200-1700. A Study of Form and Usage (Durham theses, Durham University).

Wieczorek-Kańczura K. (2018), Dom i jego wyposażenie. Między kuchnią a stotem. Wyposażenie kuchni, „Wratislavia Antiqua”, 23, s. 272-296.

Wieczorek-Kańczura K., Szajt J. (2018), Dom i jego wyposażenie. Między kuchniq a stotem. Noże, pochewki i okucia pochewek na noże, „Wratislavia Antiqua”, 23, s. 296-322.

Wiśniewski Z. (1993), Inwentarz zabytków ruchomych pozyskanych podczas eksploracji zasypiska wewnętrznej fosy miejskiej w obrębie wschodniej części placu Dominikañskiego, "Silesia Antiqua”, 35, s.331-354.

Włodarska B. (1975), Cyna. Katalog zbiorów Muzeum Narodowego w Gdańsku, Krajowa Agencja Wydawnicza, Gdańsk.

Wrak statku General Carleton, 1785 (2008), W. Ossowski (red.), Polish Maritime Museum, Gdańsk.

Wühr H. (196I), Altes Essgerät, F. Schneekluth, Darmstadt.

Zdaniewicz R. (2013), Nowożytny depozyt przedmiotów metalowych z okolic Gliwic-Czechowic, „Rocznik Muzeum w Gliwicach”, 24, s. 405-4I8.

\section{Źródła internetowe}

http://collections.vam.ac.uk/item/O271838/spoon-unknown/ [I IV 2019] http://www.gedanopedia.pl/gdansk/?title=STARE_MIASTO [24 VI 20I9]. https://gdansk.fotopolska.eu/696150,foto.html [25 VI 2019].

https://www.gedanopedia.pl/gdansk/?title=FORTYFIKACJE [24 VI 2019]. 
https://www.gedanopedia.pl/gdansk/?title=M\%C3\%96LLER_ANTON [26 IX 202I]. https://www.gedanopedia.pl/gdansk/?title=Strona_g\%C5\%82\%C3\%B3wna [24 VI 2019]. https://www.gedanopedia.pl/index.php?title=OSIEK [26 VI 20I9]. https://www.nuernberger-hausbuecher.de/75-Amb-2-279-6I-r [26 IX 202I]. https://www.nuernberger-hausbuecher.de/75-Amb-2-279-II3-v [26 IX 202I]. https://www.nuernberger-hausbuecher.de/75-Amb-2-317-49-r [26 IX 202I]. https://www.nuernberger-hausbuecher.de/75-Amb-2-317-I42-r [26 IX 202I]. https://www.nuernberger-hausbuecher.de/75-Amb-2-317b-17-v [26 IX 2021]. https://www.nuernberger-hausbuecher.de/75-Amb-2-317b-6-v [26 IX 202I]. https://www.nuernberger-hausbuecher.de/75-Amb-2-317b-154-v [26 IX 202I]. https://www.nuernberger-hausbuecher.de/75-Amb-2-317b-182-v [26 IX 202I]. https://www.nuernberger-hausbuecher.de/75-Amb-2-317b-203-v [26 IX 202I]. https://www.wga.hu/art/f/flegel/stil_oys.jpg [26 IX 202I] . https://www.wga.hu/frames-e.html?/html/b/bouts/dirk_e/lastsupp/index.html [26 IX 202I]. https://www.wga.hu/frames-e.html?/html/c/claesz/roemer4.html [26 IX 202I]. https://www.wga.hu/html_m/b/beert/elder/cherries.html [26 IX 202I]. https://www.wga.hu/html_m/d/david/2/cana_mas.html [26 IX 202I]. https://www.wga.hu/html_m/f/flegel/stil_che.html [26 IX 202I]. https://www.wga.hu/html_m/k/kraen/banquet.html [26 IX 202I]. https://www.wga.hu/html_m/m/mahu/breakfas.html [26 IX 202I]. https://www.wga.hu/html_m/p/passerot/butcher.html [26 IX 202I]. https://www.wilanow-palac.pl/dekoracje_sztuccow.html [23 VI 2019].

\section{Summary}

Due to a development plan concerning the plot at 40 Wałowa Street, archaeological works were carried out in its area in the years 2016-2017. The history of the research area was strongly influenced by its location in the contact point of three zones: Osiek, the Old Town and the Young Town. In the Middle Ages, a moat being part of fortifications was located in this place, while modern period fortifications of the northern front were built there in the $17^{\text {th }}$ century. An extension of the zone within the ring of fortifications was related to filling up of the medieval moat. Garbage from the area of Gdańsk was in all probably used for this purpose. The fortifications ceased to fulfil their role and were dismantled in the I890s. In the case of the examined area plots were then used for barracks buildings. These were destroyed in 1945 and no development activity took place there until the time of research.

The paper offers a discussion of $3 \mathrm{I}$ finds acquired from the site at 40 Wałowa Street in Gdańsk. These artefacts were used for preparation and consumption of meals. In this work it was also attempted at completing the bibliography of modern period kitchen artefacts and those related to table culture. The artefacts discussed in the paper include I5 spoons, I3 knives, including one which forms a set with a fork, another two-pronged fork, as well as a tin tankard. Knives are a category of finds which is dealt with as 
a separate group in scholarly literature. Attempts at a functional classification have been undertaken within this group. As regards the finds from 40 Wałowa Street, the first criterion of classification was the original application of the artefacts. On the basis of this criterion the discussed assemblage was limited to i2 table knives and one kitchen knife. What was analysed was the form and ornament of the artefacts as well as the issue of manufacturer's marks. A special attention was paid to the set of cutlery composed of the knife and the two-pronged fork, as well as to another fork of this type. These artefacts may have been used for serving meals from platters. The second group of artefacts were spoons. These included I2 pieces of cutlery and one kitchen spoon. Also in this case the morphology, ornamentation, as well as marks on the artefacts were dealt with. Some of the finds can be related to local workshops or even to a Gdańsk manufacturer who is known by name, that is, a non-guild craftsman Peter Draland. The tin tankard is an exceptional find which increases the exhibition value of the assemblage. The author of this paper knows merely three tin pieces of tableware, such as Hanseatic jugs and a salt-cellar which were discovered in the course of excavations in Gdańsk. Artefacts made from this metal, due to related financial and social aspects such as a considerable interest from purchasers, quality issues and problems of guild fights against non-guild craftsmen, were also a point of departure for a broader reflection on Gdańsk bronze and tin crafts.

The discussed artefacts were acquired from a context dated to the period from the second half of the $16^{\text {th }}$ to the $18^{\text {th }}$ century. The lion's share of finds $(23)$ were revealed within an $\mathrm{I}^{8^{\text {th }}} \mathrm{c}$. well. However, most of these artefacts (19) were dated to the $17^{\text {th }}$ century (19). Concerning the remaining ones (IO), their chronology encompassed the $16^{\text {th }}$ and $17^{\text {th }}$ centuries. Sporadically, the finds were dated to the $15^{\text {th }}-16^{\text {th }}(\mathrm{I})$ or to the $18^{\text {th }}$ century $(\mathrm{I})$.

Research on metal kitchen and table utensils in Gdańsk in the Modern Period calls for further analyses which should be based on a more numerous assemblage of finds. What is recommended is to process a higher number of artefacts which were acquired in the course of excavations and which are now solely known from museum inventories. It must be stressed that a high significance of the issues of kitchen and table culture consists both in their strong research potential and in considerable opportunities of using these problems for archaeological education and popularisation activities.

\section{Translation Grzegorz Żabiński}

Keywords: Kitchen artefacts, tableware: knives, spoons, tankard, brass and tin crafts, manufacturer's mark

\section{Marta Wołyńska}

Muzeum Narodowe w Gdańsku

e-mail: wolynska@archeolog.gdn 